\title{
Tweaking mesenchymal stem/progenitor cell immunomodulatory properties with viral vectors delivering cytokines
}

Paola Quaranta, ${ }^{1}$ Daniele Focosi, ${ }^{2}$ Giulia Freer, ${ }^{1,3,}{ }^{*}$ and Mauro Pistello ${ }^{1,3, *}$

${ }^{1}$ Virology Section and Retrovirus Center, Department of Translational Research and New Technologies in Medicine and Surgery, University of Pisa, Pisa, Italy.

${ }^{2}$ North-Western Tuscany Blood Bank, Pisa University Hospital, Pisa, Italy.

${ }^{3}$ Virology Unit, Pisa University Hospital, Pisa, Italy.

*These Authors contributed equally to the study

Corresponding author:

Dr. Mauro Pistello

Virology Section and Retrovirus Center

Department of Translational Research and New Technologies in Medicine and Surgery

University of Pisa

Via San Zeno, 37

I-56127 Pisa Italy

E-mail: mauro.pistello@med.unipi.it

Ph. +39050 2213781

Fax +390502213524

Running Title: Engineering Mesenchymal Stem Cells with Exogenous Cytokines

Keywords: mesenchymal stem cells; MSC; gene therapy; immunomodulation; cytokines; viral vector 
Abbreviations:

AAV: adeno-associated viruses

Adv: adenoviral

ALS: amyotrophic lateral sclerosis

AT: adipose tissue

AT-MSCs: adipose tissue-derived MSCs

BM: bone marrow

CNS: central nervous system

DC: dendritic cell

EAE: experimental autoimmune encephalomyelitis

FDA: Food and Drug Administration

FGF: fibroblast growth factor

GVHD: graft-versus-host-disease

HGF: hepatocyte growth factor

IL: interleukin

IL-1Ra: interleukin-1 receptor antagonist

IFN- $\gamma$ : interferon- $\gamma$

IRI: ischaemic reperfusion injury

ISCT: Mesenchymal and Tissue Stem Cell Committee of the International Society for Cellular Therapy

Kbp: Kilobase pairs

LV: lentiviral

MS: multiple sclerosis

MSCs: mesenchymal stem cells

NK: natural killer

SDF-1: stromal derived growth factor

SLE: systemic lupus erythematosus

SOT: solid organ transplantation

TGF- $\beta$ : transforming growth factor- $\beta$

TNF- $\alpha$ : tumor necrosis factor- $\alpha$

Th: T helper lymphocytes

T-reg: regulatory T-cell

UC: umbilical cord 
UCB: umbilical cord blood

UC-MSCs: umbilical cord derived MSCs

UCB-MSCs: umbilical cord blood derived MSCs

VEGF: vascular endothelial growth factor

WJ: Wharton's Jelly

WJ-MSCs: Wharton's Jelly derived MSCs

Wt: wild type 


\begin{abstract}
Mesenchymal Stem Cells (MSCs) can be found in various body sites. Their main role is to differentiate into cartilage, bone, muscle and fat cells to allow tissue maintenance and repair. During inflammation, MSCs exhibit important immunomodulatory properties that are not constitutive but require activation, upon which they may exert immunosuppressive functions. MSCs are defined as "sensors of inflammation" since they modulate their ability of interfering with the immune system both in vitro and in vivo upon interaction with different factors. MSCs may influence immune responses through different mechanisms, such as direct cell-tocell contact, release of soluble factors, and through the induction of anergy and apoptosis. Human MSCs are defined as plastic-adherent cells expressing defined surface molecules. Lack of MHC class II antigens makes them appealing as allogeneic tools for the therapy of both autoimmune diseases and cancer. MSC therapeutic potential could be highly enhanced by the expression of exogenous cytokines provided by transduction with viral vectors. In this review, we attempt to summarize the results of a great number of in vitro and in vivo studies aimed at improving the ability of MSCs as immunomodulators in the therapy of autoimmune, degenerative diseases and cancer. We will also compare results obtained with different vectors to deliver heterologous genes to these cells.
\end{abstract}




\section{Introduction}

MSCs were isolated from the bone marrow (BM) for the first time in the 1970's by Friedenstein [1]. The term "Mesenchymal Stem Cell" was introduced by Caplan in the 1980's after discovering MSC ability to differentiate into mesodermic cells: chondrocytes, tenocytes and myoblasts [2]. It was recognized that MSCs meet adult stem cell criteria, such as selfrenewal and differentiation potential [3]. Soon after their discovery, the problem arose as to whether the term "stem cell" was appropriate, since only a small fraction of cultured MSCs qualify as stem cells according to the generally accepted criteria [4]. In 2005, the new expression "multipotent mesenchymal stromal cells" (maintaining the acronym MSCs) was proposed to describe these fibroblast-like plastic-adherent cells. It was also proposed to use the term "MSCs" only for cells that meet specified stem cell criteria [4]. Caplan defined MSCs as "the sentinels and safe-guards of injury". He suggested that the main role of MSCs is protection from injuries and proposed to change their name into "Medicinal Signaling Cells" to keep the same acronim [5].

The discovery of a pool of multipotent cells present virtually in every tissue of adult animal raised great enthusiasm in the hope they could be used in cell therapy, without limitations by those ethical concerns that have hindered the use of embryonic stem cells [6].

Among their properties, MSCs also exhibit immunomodulating ability. Their application in treating several pathologies has been largely investigated both in preclinical models and in clinical trials [https:Ilclinicaltrials.gov]. Currently, naïve hMSCs are employed in a large number of clinical trials successfully and, as a result, the first cell-based therapy based on allogenic MSCs-derived drug has been approved by the Food and Drug Administration (FDA) [7].

Since 2002, numerous attempts at improving MSC immunomodulatory potential by engineering them with various cytokines have been carried out [8-10]. Several viral vectors have been used to deliver heterologous genes in vitro and in vivo to engineer MSCs. Adenoviral (Adv) and retroviral vectors were used extensively to tweak MSC properties in experimental settings and most studies agree that such procedures are likely to ameliorate MSCs as cells in therapy [11] [see Tables 2 and 3]. Unfortunately, all these studies are at a preclinical stage, therefore the major future goal will definitely be to test modified MSCs in clinics. 


\section{MSC generation and innate properties}

\subsection{Sources}

MSCs were initially isolated from the BM by a low-yield invasive process [12,13]. For this reason, other sources of cells were explored. Presently, MSCs may be derived from almost every tissue [14,15]: adipose tissue (AT) [16], lymphoid organs (thymus and spleen) [17], peripheral blood [18], endometrium and menstrual blood, scalp tissue, periodontal ligament, as well as placenta, amniotic fluid [19], umbilical cord blood (UCB) [20] and Wharton's Jelly (WJ) [21,22]. The therapeutic effect of hMSCs depends on many parameters such as tissue source of isolation, the methods of purification and the animal model used to assessed their efficacy; indeed, encouraging results in animal models not always meet expectations in clinical trial, as discussed later [23]. Thus, even if MSCs derived from different sources may meet generally accepted criteria, they may differ in proliferation rate and differentiation potential [24].

Sources alternative to $\mathrm{BM}$ were also explored to attain higher proliferative potential and a more accessible source [15,19]. Currently, one of the main sources of MSCs is AT because it is readily available, the harvest procedure is less invasive than BM aspiration and the yield of MSCs is very high [16]; indeed, AT has 500 times richer in MSCs than BM [25]. AT-derived MSCs (AT-MSCs) proliferate rapidly in vitro and show low levels of senescence even after months of in vitro culture [26]. Nevertheless, isolation and expansion of AT-MSCs is somewhat less prone to automation in bioreactors.

Wharton's jelly derived MSCs (WJ-MSCs) are also often used, since they are abundantly available after childbirth. Compared to the other sources, they are ontogenically primitive [21]. Most Authors agree on the fact that they have higher proliferative potential compared to both AT and BM [15]. In contrast, Bortolotti et al. showed that hBM-MSCs grow faster in vitro and have higher proliferative potential than AT-MSCs even though they only survive to passage 12 of culture then become senescent [23].

\subsection{Definition}

MSCs are generally characterized by expression of CD105 (SH2), CD73 (SH3 or SH4), CD90, CD166 (VCAM), CD44, CD 54/102 (ICAM1-2) CD 157, CD49, and Stro-1, and lack of CD11b, CD14, CD31 and CD45 (which identify hematopoietic or endothelial cells) [12]. 
Phenotypic markers alone are not sufficient to identify hMSCs unequivocally, because the former can be expressed by other cell types as well; furthermore, during culture expansion, phenotypic marker expression can change, probably due to ageing of cells [27]. Different tissue origin, procedures of isolation, and culture conditions of MSCs in different laboratories produce heterogeneity of cell populations obtained [23]. This makes it hard to compare the biological properties and experimental outcomes in cell therapy trials. Therefore, the Mesenchymal and Tissue Stem Cell Committee of the International Society for Cellular Therapy (ISCT) proposed a set of standards to define human MSCs unambiguously [28]. According to such criteria, MSCs are defined as a plastic-adherent population (when cultured in standard conditions), phenotypically expressing CD105, CD73, CD90 for more than 95\% of the population and lacking expression of CD45, CD34, CD11b or CD14, CD 19 or CD79a, and HLA class II ( $\leq 2 \%$ positive). Moreover, MSCs must be able to differentiate to osteocytes, adipocytes or chondrocytes when cultured in appropriate differentiation media. These criteria apply only to human MSCs because cells derived from other species (such as rat and mouse) show different phenotypic markers [29].

All MSCs show similar phenotypes and functional features [15]. However, there are a number of differences that depend on their micro-environmental niche, original local function (stromal support of hematopoiesis in the BM vs immune homeostasis by AT), and ontogenetic age (birth-associated vs adult) [15]. For instance, CD106 is significantly reduced on ATMSCs compared to other MSCs [15]. Certain differences in potency may also exist: while AT-MSCs have multi-lineage differentiation potential in vitro and in vivo [30], there are conflicting reports regarding cord tissue-derived MSCs. Mattar and Karagianni reported that UCB-MSCs have significantly less adipogenic differentiation capacity [31]. Very recently, Reinisch also showed that only BM-MSCs are capable to form a functional hematopoietic niche [32].

All studies agree on the ability of all MSCs carry out immunomodulation; in this respect, ATMSCs proved to be more efficient than MSCs from other sources [24]. At present, comparative studies on MSCs do not consider the variables affecting their immunomodulatory efficacy, but only compare properties of cells in vitro, such as phenotypic markers, multipotency, and angiogenic ability ex vivo [23].

In conclusion, there is no consensus on the best source or culture method for MSC isolation because cells vary in their therapeutic efficacy depending on the model considered [6].

\subsection{Properties}


BM-MSCs support hematopoiesis by producing extracellular matrix components, such as cytokines and growth factors, in BM and most other tissues. Their main physiological role is to promptly mobilize and differentiate in response to signals of pathological or traumatic nature [33]. They actively respond to stress and injury, and can promote angiogenesis and regeneration.

Recently, pericytes were recognized as MSCs, i.e. perivascular cells forming a unique niche, appointed to maintain the integrity of blood vessels. Pericytes can indeed be isolated from the $\mathrm{BM}$ and exhibit the same characteristics of MSCs [34,35]. They are positive for phenotypic markers CD10, CD13, CD44, CD73, CD90, CD105 and negative for CD56, CD106, CD133 [36]; in addition, they are able to differentiate into MSC lineages both in vitro and in vivo $[14,36]$. Perivascular location of MSCs is essential for their fast recruitment at the site of damage or inflammation.

MSCs downregulate activated immune cells and reduce damage to the site of inflammation, therefore they may be considered one of the most important mechanisms of defence against excessive autoimmune reactions [5]. When stimulated by environmental signals of inflammation, MSCs release several molecules suppressing the immune response so that they can escape immune surveillance and easily migrate towards the site of injury [5]. Therefore, they can have many applications in immunotherapy, for example in the treatment of degenerative and inflammatory pathologies. Immunomodulatory properties have been widely demonstrated for all MSC populations, independently of their source of isolation, both in preclinical and clinical trials. However, AT-MSCs showed stronger effects compared to others models [24,37]. Since interaction of MSCs with cells of the immune system is very complex and often mutually dependent, many Authors disagree on the mechanisms involved in immunomodulation; for this reason, the ISCT has also proposed standardized guidelines and protocols for their immunological characterization [38].

As mentioned above, MSCs may suppress or stimulate immunity depending on their surrounding. MSC immunomodulatory ability is not constitutive but requires activation in a pro-inflammatory environment [6]. It has been shown that interleukin-1 (IL-1), interferon- $\gamma$ (IFN- $\gamma$ ), and tumor necrosis factor- $\alpha(\mathrm{TNF}-\alpha)$ are involved in the priming of MSCs, which consequently interact with cells of both innate and adaptive immunity [6,7]. MSCs may alter cytokine secretion by dendritic cells (DCs) preventing their maturation and activation [39,40], suppress $\mathrm{T}$ cell and natural killer (NK) cell proliferation and their cytokine production [41] and B cell functions [41,42]. 
MSCs may influence immune activity through different mechanisms, such as direct cell-tocell contact, release of soluble factors, and through the induction of anergy and apoptosis [7]. Interaction with the immune cells takes place via expression of a large number of adhesion molecules, like VCAM-1, ICAM-1, LFA-3, HLA and MHC-I, expressed on MSC surface $[12,43]$. Because they lack MHC-II and costimulatory molecules such as CD40, CD80 or CD86, MSCs are considered "immuno-priviledged" cells and good candidates for allogeneic transplantation [44], with the caveat that, in inflammatory conditions, up-regulation of MHCII can increase their immunogenicity [45]. However, MSCs immunogenicity observed in certain studies may be due to the use of undefined serum or plasma for cell culture, rather than to MSCs themselves [46]. Currently, the question on MSC immunogenicity is being debated and under investigation.

MSCs release many soluble factors, including transforming growth factor- $\beta$ (TGF- $\beta$ ), hepatocyte growth factor (HGF) [47], nitric oxide [48], indoleamine 2,3-dioxygenase [49], prostaglandin E2, interleukin-10 (IL-10), interleukin-1 receptor antagonist (IL-1Ra), interleukin 6 (IL-6), leukocyte inhibitory factor, HLA-G, hemeoxygenase, TNF- $\alpha$, and many others. A pivotal role is played by IL-10 that supports the differentiation of regulatory T cells (T-regs). The ability of MSCs to induce T-regs has been observed both in vitro and in vivo [6, 50-52]. MSCs activate macrophages derived from circulating resident monocytes and initially polarize them to M1 profile [6, 53]. Upon the influence of inflammatory cytokines released by M1 macrophages, MSCs start skewing macrophages towards the M2 subtype by a feedback mechanism [54].

\section{Innate immunomodulation properties of MSCs and their exploitation in clinic}

The ability of MSCs to tightly interact with immune cells has been explored to treat many diseases where a pivotal role is performed by the immune system. Here we summarize the principal approaches.

\subsection{Immunomodulation in the therapy of autoimmune and degenerative diseases}

The first pioneering study on the effect of MSCs administration in vivo was performed more than 10 years ago for the treatment of graft-versus-host-disease (GVHD), a syndrome given by activation of donor $\mathrm{T}$ cells against recipient tissues after BM transplantation [55]. Severe acute GVHD is often refractory to immunosuppressants and has been reported to have an 
overall 2-year survival of 5-30\% [56]. In this regard, MSCs represent the main alternative to drugs. In the study mentioned above, haploidentical third-party MSCs were compassionately administered to a 9-year-old boy with steroid-resistant grade-IV GVHD, who completely healed after a year. The success of the therapy opened the way to clinical trials for treatment of GVHD with MSCs.

At present, phase II/III multicenter clinical trials have confirmed the efficacy of MSC treatment on adult and pediatric patients affected by steroid-resistant GVHD both in the USA and in Europe. Most importantly, third-party-derived MSCs were shown to be safe as allogeneic cells [57,58]. As a result, the drug Prochymal ${ }^{\mathrm{TM}}$ (Osiris Therapeutics Inc., Columbia, MD, USA), based on allogenic MSCs derived from the BM of adult donors, was approved by the FDA to treat acute GVHD. Currently, Prochymal ${ }^{\mathrm{TM}}$ is being tested in two phase-III clinical trials on newly diagnosed patients (NCT00562497) and on steroid-refractory GVHD (NCT00366145). While the effect of MSC administration in acute GVHD has been demonstrated, their efficacy against chronic disease still needs further investigation: so far, chronic patients seem to be less responsive $[59,60]$. Therefore, efficacy of MSC therapy for the treatment of chronic GVHD is still unclear.

After the extraordinary results obtained in acute GVHD, MSC therapy was also tested in the field of solid organ transplantation (SOT) as an alternative to immunosuppressive drugs, with the aim to prevent acute graft rejection and failure. Indeed, there are major concerns about the currently used immunosuppressants; their side effects vary from acute and chronic nefrotoxicity, hypertension, hepatotoxicity and neurotoxicity, as well as an increased risk gastrointestinal disorders and diabetes [61-63]. Moreover, SOT is often followed by ischemia-reperfusion injury (IRI) that, in turn, causes systemic inflammation. This event can lead to delayed function and primary dysfunction of graft. In the past, several studies performed in preclinical models showed the ability of MSCs to reduce IRI, preventing graft rejection, and to promote immunotolerance in SOT [64-68]. Since then, clinical trials have been carried out where MSCs proved to be successful alone or in association with low doses of immunosuppressive drugs in kidney transplantation [69,70]. Currently, a phase I/II clinical trial is testing MSCs for liver transplantation. However, preliminary results obtained in clinical trials are less satisfactory than expected on the basis of the results on animal models.

MSCs have been used for the treatment of other autoimmune diseases, a category of pathologies where malfunctioning of the immune system is a determining factor. Administration of MSCs appears to be a promising therapy also in pancreatic islet transplantation for the treatment of type-I diabetes, an autoimmune disease triggered by the 
immune response against autoantigens of $\beta$-cells. The effects of MSCs have been largely studied and clear evidence showed that MSCs can suppress autoimmunity against islets, support neo-angiogenesis in damaged microvasculature of islets and prevent acute rejection [67,71,72]. At present, more than 20 phase I/II clinical trials employing allogeneic MSCs or Prochymal $^{\mathrm{TM}}$ for the treatment of diabetes are underway.

MSCs have been also tested in Crohn's disease, a chronic condition where the immune system attacks the gastrointestinal tract. A phase-I clinical trial has been performed by infusion of autologous MSCs in patients that did not respond to conventional treatment. Results showed an improvement of the disease with no significant adverse events either during BM harvesting or after MSC infusion; only mild allergic reactivity was observed in one patient probably due to dimethylsulfoxide used to cryopreserve cells. The administration of autologous BM-MSCs seems to be a safe and feasible therapy for the treatment of refractory Crohn's disease [73]. At the time of writing, Prochymal ${ }^{\mathrm{TM}}$ is being tested in Crohn's disease in a phase-III clinical trial (NCT01233960). Since Crohn's disease is often associated with the formation of perianal fistulae, autologous AT-MSCs have also been employed in their treatment with promising results and a phase-II clinical trial is being carried out [74].

Multiple Sclerosis (MS), a neurodegenerative pathology of the central nervous system (CNS) characterized by focal demyelination, neuronal damage, glial cell activation and massive infiltration of immune cells, is thoroughly studied [75]. In the pathogenesis of MS, the inflammatory response is associated to an autoimmune reaction where both cellular and humoral components are activated against antigens of the CNS [76]. The neurodegenerative process, instead, is responsible for increasing disability in MS, because it induces neuronal and axonal loss and leads to brain atrophy [77]. MSC transplantation has been proposed as a cell-based therapy for MS, in alternative to the one in use. In experimental models, MSCs seem to protect CNS from autoimmune demyelination; the observed therapeutic effect is thought to be mainly due to release of cytokines and chemokines, which suppress inflammation and enhance proliferation, migration and differentiation of endogenous stem/progenitor cells [78]

Despite the promising results derived from experimental animal models of MS, the efficacy of MSC treatment in clinical trials is less evident. In a pilot study performed on 10 patients affected by MS, only 6 showed improvement in the disease as a result of intrathecal injection of MSCs; in addition, 12 months after treatment, no improvement was evident by magnetic resonance [79]. Furthermore, in a phase-I and, more recently, in a phase-II clinical trial, intrathecal administration of MSCs induced modest improvement of only certain specific 
parameters related to vision impairment $[80,81]$.

The most encouraging results have been obtained in the treatment of systemic lupus erythematosus (SLE), an autoimmune inflammatory disease with multiorgan involvement including renal, cardiovascular, neural, musculoskeletal, and cutaneous systems. SLE is often refractory to conventional therapies based on corticosteroid administration [82]. Recently, SLE has been demonstrated to be a stem cell disorder caused by a defect in BM microenvironment [83]. Accordingly, MSCs derived from patients with SLE exhibited impaired proliferation, differentiation, and immune modulation capacities [84]. Moreover, the main features of SLE are alteration in cytokine homeostasis and defects in T-reg development [85]. In the light of such premises, allogenic MSC transplantation seems the best approach for treatment of the disease. In a pilot study performed on SLE patients refractory to standard treatment, administration of allogeneic MSCs proved to ameliorate renal functions and restore T-reg cells, with no side effects observed [86].

Controversial results have been obtained by employing MSCs in preclinical models of rheumatoid arthritis, a systemic autoimmune disorder mediated by $\mathrm{T}$ cells and characterized by chronic inflammatory synovitis and progressive joint destruction. Alteration of autoreactive $\mathrm{T}$ cells and inflammatory cytokines such as TNF- $\alpha$ play a pivotal role in the pathogenesis of the disease [87-89]. Currently no clinical trials have started.

In contrast, MSC therapy has proved clearly effective in the treatment of other inflammatory disease, such as stroke [90,91], asthma [51], allergic rhinitis [92], lung injury [93], colitis, sepsis. In this context, experiments in mice showed that MSC administration in murine models of experimental colitis and sepsis reduced the severity of the disease by inducing M2 polarization and the secretion of anti-inflammatory cytokines [94-96]. MSC therapy has been also tested for the treatment of amyotrophic lateral sclerosis (ALS) a neurodegenerative disease which rapidly induces loss of motor neuron function. The pathophysiology of the disease is poorly understood but it is believed that the immune response could also play a crucial role. In a phase-I clinical trial performed with 10 patients, BM-MSCs were transplanted into the spinal cord: no side effects were observed [97]. In another phase I/II clinical trial, involving both ALS and MS patients, autologous MSCs were administered both intrathecally and intravenously to maximize homing to the CNS. In ALS patients, functional improvement was evident and only mild side effects were observed, probably due to residual dimethylsulfoxide. Moreover, an increase of CD4+, CD25+, Foxp3+, and T-regs and downregulation of activated lymphocytes and antigen-presenting cells were reported, whereas T-regs are normally reduced in patients with rapid disease progression $[98,99]$. The excellent 
outcomes and lack of safety concerns pave the way for other phase-II trials.

\subsection{Immunomodulation in the therapy of cancer}

MSCs are also able to adopt a pro-inflammatory phenotype [6,53]: they are able to recruit neutrophils through the production of chemokines, and enhance their pro-inflammatory activity through the production of IL-6, IL-8, GM-CSF and migration inhibitory factor [100,101]; in vivo murine MSCs strongly increase T cell proliferation [48,102,103]. Since MSCs exhibit immunostimulatory properties, the application of MSCs in anticancer therapy has been explored. MSC homing ability towards the sites of injury is well known, but several studies demonstrated that they are also driven toward tumor sites and incorporated within the connective tissue stroma of tumors after intravenous injection [104]. Both in vitro and in vivo tests proved that MSCs home into glioma, both after intraarterial and local intracranial delivery. This process is mediated by growth factors and chemokines [104,105]. MSCs injected in vivo have been shown to distribute mostly at the border between cancerous and normal parenchyma and also uniformly infiltrate into the tumor bed while no MSCs were observed in healthy organs [8,104-106]. At present, the mechanisms involved in MSC migration are unknown, but two possible alternatives have been hypothesized: homing of MSCs may be favoured by the secretion of chemokines/cytokines by tumor tissues; alternatively, the interaction of cytokines or chemokines with their receptors might induce migration of MSCs towards the tumor microenvironment. Several studies have suggested that both cytokines, such as vascular endothelial cell growth factors (VEGF), TGFs, fibroblast and platelet-derived growth factors, monocyte chemoattractant, protein-1, and IL-8 $[106,107]$ and adhesion molecules, such as $\beta 1$ - and $\beta 2$-integrins and L-selectin, could be involved $[108,109]$. Furthermore, MSCs express several receptors like CXCR4, CX3CR1, and many others, which interact with their specific ligands [110]. CXCR4 and stromal cell-derived factor-1 (SDF-1) seem to play the main role, in the migration of MSCs towards the tumor site and in the pathology of glioma [111]. The extraordinary ability of MSCs to "sense tumor" has been exploited to deliver several anti-cancer gene products to tumor cells in vivo [8, 112]; particularly 3 of the gene products have received the most attention: IL-2 [106], IFN- $\beta$ [8, 112], and tumor necrosis factor-related apoptosis-inducing ligand (TRAIL) [113].

Although MSCs look promising for cancer therapy, their antitumor effects are still controversial. Some Authors showed that unmodified MSCs inhibit tumor growth and angiogenesis [114,115], while others report that MSCs support tumor development and 
metastasis [116]. Consequently, further preclinical studies are warranted before clinical trials can be started.

\section{Enhancing MSC immunomodulatory properties by exogenous gene transfer}

The therapeutic potential of MSCs can be altered and routed by gene delivery. Indeed, delivery and expression of specific exogenous genes can yield MSCs releasing soluble factors, expressing specific receptors, conferring migratory ability or actions in response to specific stimuli, etc.

The idea of using exogenous cytokines to, for instance, stimulate antitumor responses is not new. Direct administration of cytokines was attempted twenty years ago [117], whereas delivery of IL-2, IL-12, IFN- $\beta$ and yet other cytokines by viral vectors is more recent [118][202]. Both strategies have drawbacks: because of difficulties in reaching tumor sites and their short half-lives, free cytokines need to be inoculated at high doses and repeatedly, thus increasing their toxicity. In vivo injection of viral vectors, on the other hand, does not ensure specific targeting and is associated with safety concerns [118]. Thus, local cytokine delivery through engineered MSCs is a more promising, safe, and effective approach.

The main obstacle to the development of such MSC-based therapeutic approaches is the inherent resistance of MSCs to most transfection and transduction strategies. Transfection, which implies the use of plasmids, transposons, RNA or other molecular constructs can be achieved by treating cells with microprecipitates of nucleic acid-Calcium complex, electroporation, liposomes, etc. These methods have become routine and are successfully used on a wide variety of adherent and suspension culture cells [119]; further, since molecular constructs do not integrate into the host cell genome, or are silenced/eliminated a few days after transfection, this approach presents a highy safe profile and is, therefore, preferable for clinical use. Unfortunately, the very poor performances shown with MSCs make these methods inapplicable for MSC-based therapeutic approaches.

Gene transfer in MSCs has been mostly carried out with vectors derived from Adv, adenoassociated viruses (AAV), and lentiviruses (LV). As detailed in Table 1, these vectors have pros and cons and provide a wide choice of approaches ranging from transient to permanent modification of cells, constitutive or inducible expression of the transgene - i.e. the heterologous gene delivered by the vector -, delivery of one or more transgenes, etc. Detailed description of Adv, AAV, and LV vectors is available elsewhere [120]. Here we focus on same characteristics with particular reference to MSC transduction. 


\subsection{Adenoviral vectors}

Adv vectors, a schematic is available in Figure 1A, transduce dividing and non-dividing cells. Their DNA genome persists as an episome for a few days, ensuring transient, high level expression of the transgenes. For this feature Adv vectors are considered safe but gene modification is short-lasting and is not transmitted to progeny cells. For these reasons, Adv vectors are used for vaccination purposes or transient cell manipulation [120-122].

MSCs lack the Adv receptor and are therefore basically resistant to Adv vector transduction [123]. High vector/cell ratio is therefore necessary to transduce hBM-MSCs possibly causing various toxic effects and strong immune reactions in vivo [8]. Ongoing studies to improve efficiency of MSC transduction aim to generate recombinant vectors bearing other viral receptors [124-127] or using cationic polymers, chelating agents, or small peptides to reduce electrostatic repulsions [128-130]

\subsection{Adeno-associated viral vectors}

Parental AAV viruses infect a wide range of cells in vivo and insert their viral genome in a specific and harmless site of the cellular genome. AAV vectors transduce both dividing and non-dividing cells, exhibit minimal immunogenicity and toxicity but, having a small genome, can transport minute amounts of heterologous genetic material and, owing to deletion of a substantial part of the viral genes, have lost the capacity to integrate into the host cell genome (Table 1). Despite these limitations, AAV vectors elicit long-term transgene expression in vivo and are used in large number of clinical trials.

Initial studies have shown that AAV vector transduce MSCs without altering their multipotential ability but establish low level of transgene expression [131-133] have shown that there is ample room for improvement [132,134-137].

\subsection{Lentiviral vectors}

LV vectors transduce both quiescent and dividing cells and integrte teir vector genome into the host cell genome thus ensuring long-lasting expression of the transgene [138] For these and other features shown in Table 1 are the most used vectors for gene therapy. Transduction of MSCs with LV vectors has been extensively investigated [11,139]. In their simplest 
version (i.e. single transgene controlled by a standard cytomegalovirus immediate early promoter) and using a low vector/cell ratio, LV vectors transduced over 25\% human BMMSCs and expressed the transgene for over 5 months in vitro [139]. Also, transduction did not alter MSC phenotype, in vivo homing, viability, proliferation of cells, nor ability to differentiate into adipocytes and osteocytes[11,140,141]. Like AAV vectors, MSC transduction went up to $95 \%$ with $\mathrm{LV}$ vectors bearing different constitutive or inducible promoters [11,142], using synthetic polymers to reduce electronic repulsion [140] and/or, a second transgene to sort transduced cells $[143,144]$. High efficiency of transduction and, the capacity to carry two or more transgenes make LV vectors the system of choice for MSC transduction as it permits, for instance, to deliver reporter genes to monitor localization, viability, and, differentiation pathway of the engineered cells $[9,145]$

\section{Alteration of MSCs immunomodulation properties by gene transfer}

MSCs have been transduced with the vectors described above and carrying transgenes capable of enhancing or counteracting immunosuppressive properties of naïve MSCs. In the following sections, we summarize the main studies performed and the results obtained.

\subsection{Enhancing MSC immunosuppression}

These studies are based on the delivery of the following anti-inflammatory cytokines (also enlisted in Table 2).

\section{Interleukin-1 receptor antagonist}

IL-1 $\alpha$ and IL1- $\beta$ play a pivotal role in chronic inflammation and in the activation of innate immunity. IL- $1 \alpha$ is released by a variety of cells undergoing necrosis, for example after epithelial damage, myocardial infarction, stroke, tumour decay or acute renal failure and may be considered an "alarmin", since it induces production of IL-1 $\beta$, TNF- $\alpha$ and IL-6 [146,147]. IL-1 $\beta$ is released by monocytes, macrophages, neutrophils and DCs. It is a potent proinflammatory cytokine locally causing vasodilatation, granulocytes chemotaxis into damaged tissue and expression of prostaglandins. IL-1 $\beta$ also brings about activation of the proinflammatory T helper (Th) 17 cells and the development of chronic inflammation [146]. IL-1 $\beta$ plays a pivotal role in the pathophysiology of various inflammatory conditions, such as 
rheumatoid arthritis, prosthetic aseptic loosening of arthroplasty, acute liver failure, hereditary autoinflammatory diseases, rheumatoid arthritis, osteoarthritis, type 2 diabetes mellitus, cardiovascular disease and many others $[146,148,149]$.

The Interleukin -1 receptor antagonist (IL-1Ra) can be considered an antagonist of the proinflammatoy cytokines IL- $1 \alpha$ and IL1- $\beta$, since it binds their receptor blocking IL- $1 \alpha$ and IL$1 \beta$ signaling [150]. IL-1 Ra is expressed in all tissues and is present in serum at high levels. It is able to prevent uncontrolled activation by IL- $1 \beta$ both in vitro and in vivo, thereby reducing inflammation, but high concentrations are required [151]. In healthy conditions, there is a balance between the proinflammatory activities of IL- $1 \alpha$ and IL-1 $\beta$ and the ability of IL-1Ra to control their production; alteration of this equilibrium can induce inflammatory diseases [150]. IL-1Ra could be valuable to treat inflammatory diseases; indeed, the infusion of exogenous IL-1Ra is being evaluated in clinical trials against GVHD and MS.

MSCs are also able to secrete IL-1Ra [152]. They have an improved anti-inflammatory effect compared to administration of exogenous IL-1Ra [153]. Moreover, combined therapy with IL-1Ra and MSC is more efficient than the use of the two separate treatments [154]. Thus, engineering of MSCs with IL-1Ra (MSCs/IL-1Ra) potentiate IL-1Ra release. BM-MSCs/IL1 Ra have been tested both in vitro and in in vivo models of several diseases (Table 2). hBMMSCs transduced by Adv vectors expressing IL-1Ra in association with HGF (hBMMSCs/HGF/IL-1Ra) or VEGF (hBM-MSCs/VEGF/IL-1Ra) have been studied in islet transplantation for the treatment of Type-I diabetes $[155,156]$. Because IL-1 $\beta$ plays a key role in the loss of islet viability after transplantation [157], systemic administration of MSCs or their local injection in transplanted islets partially reduces inflammation, promotes revascularization and supports graft survival. However, they were not enough to completely prevent apoptotic cell death and more than $70 \%$ of islets were lost in the first weeks after transplantation $[158,159]$. It was demonstrated that engineered cells were able to secrete high levels of IL-1Ra and HGF/VEGF and, by acting in synergy, the cytokine expressing MSCs prevented apoptosis of islet cells and improved islet engraftment, thus supporting long-lasting normoglycaemia [155].

IL-1 $\beta$ hampers cartilage and bone regeneration [146]; together with TNF- $\alpha$, it hinders MSCs differentiation to chondrocytes [160]. Accordingly, an in vitro study demonstrated that MSCs engineered with IL-1Ra by an inducible LV vector, were able to support MSCs chondrogenic differentiation also in the presence of IL-1 $\beta$ [161]. The effect of MSCs therapy combined to exogenous administration of IL-1Ra resulted effective also in the treatment of acute liver failure, a pathology characterized by severe liver cell damage [162]. MSCs/IL-1Ra have not 
yet been tested in this context.

\section{Interleukin-10}

Interleukin-10 (IL-10), a pleiotropic cytokine, is considered to play a key role in quenching immune responses and is one of the most important soluble factors secreted by MSCs [163]. IL-10 has multiple immunoregulatory effects, such as down-regulation of MHC-II and costimulatory molecule expression; inhibition of DC maturation, function, and secretion of pro-inflammatory cytokines and chemokines [164]. In vivo, IL-10 secreted by naïve MSCs improved organ function and survival in a sepsis experimental model.

Since genetic delivery of IL-10 was shown to improve allograft survival in many animal models of heart or liver transplantation [165,166], MSCs genetically engineered with IL-10 were tested in a rat model of orthotopic liver transplantation. The injection of MSC/IL-10 significantly improved graft survival by increasing the expression of T-reg cell-associated cytokines (IL-10 and TGF- $\beta 1$ ), and decreasing the expression of Th-17 cell-related cytokines (IL-17, IL-6, IFN- $\gamma$, TNF- $\alpha$ and IL-23) [167]. Indeed, it was demonstrated that T-regs play an important role in inhibiting acute graft rejection and in the prevention of autoimmune diseases $[168,169]$. The ability of MSC/IL-10 to prevent liver transplant rejection was higher than the effect observed with naïve MSCs.

In vitro studies were performed with hWJ-MSCs transduced with human IL-10 (hIL-10) or Epstein-Barr virus IL-10 (v-IL10) [9,170]. vIL-10 is similar to hIL-10 but only has the immunosuppressive domain of the cytokine [169-173]. hWJ-MSC/vIL10 showed enhanced ability compared to naïve MSCs to release IL-10 in solution and increased immunosuppressive properties. They were able to act both on innate immunity by decreasing TNF- $\alpha$ production by monocytes upon LPS stimulation, and on adaptive immunity by reducing IFN- $\gamma$ release by CD3-stimulated T-lymphocytes [9].

\section{Interleukin-4}

Interleukin-4 (IL-4), like IL-10, is a pleiotropic cytokine, involved both in innate and adaptive immunity. IL-4 is secreted by Th2 cells together with IL-10 and IL-13 to quench inflammation. It is also able to stimulate proliferation of $\mathrm{B}$ and $\mathrm{T}$ cells and foster differentiation of naïve Th0 into Th2. Besides, IL-4 stimulates T-reg proliferation and chemotaxis [174]. 
Exogenous administration of IL-4 has been studied in several experimental models of autoimmunity where Th2 cells mediate disease remission, such as experimental autoimmune encephalomyelitis (EAE) as a model for MS [175-177]. Exogenous administration of IL-4 was shown to ameliorate EAE in mice through a Th1 to Th2 shift, but repeated administration of high doses of IL-4 were required [178]. Subsequently, it has been demonstrated that injection of recombinant plasmid, Adv and herpes simplex viral vectors encoding IL-4 in mice with EAE favoured remission of the disease [175,179-181]. Following these studies, AT-MSCs transduced with IL-4 by LV and transplanted at the onset of EAE were shown to be able to reduce the inflammatory immune response by shifting cytokine profile from Th1 to Th2 [182].

Pig BM-MSCs engineered with IL-4, injected into the inner ear of a guinea pig models of an autoimmune inner ear disease were broadly distributed in the inner ear restoring hearing function [183].

\section{Hepatocyte growth factor}

Hepatocyte growth factor (HGF) is a multifunctional cytokine involved in organogenesis, angiogenesis, cell proliferation, survival and motility. Recently, it has been demonstrated to have regenerative properties in myelodegenerative diseases and to be able to improve acute GVHD, suggesting that HGF also has immunomodulatory effects [184,185]. It has also been shown to act additively with TGF- $\beta$ to suppress T-cell proliferation in vitro [186].

hMSCs express varying amounts of HGF depending on their microenvironment [187]. They have been tested in several disease models after transduction with HGF. rBM-MSCs transduced with HGF were used in a rat model of liver transplantation and proved to significantly reduce graft rejection by decreasing the production of IL- 2 and INF- $\gamma$ and increasing IL-4 and IL-10 [188]. hAT-MSCs/ HGF have also been employed for the treatment of radiation-induced lung injury, where, again, they were able to reduce secretion of TNF- $\alpha$, IFN- $\gamma$, IL-6, TGF- $\beta$ and increase the expression of IL-10, thus not only reducing inflammation but also inhibiting lung fibrosis [189]. hUC-MSCs/HGF were also used for the treatment of acute kidney injury in rats, where HGF delivery improved IRI via antiapoptotic and antiinflammatory mechanisms, thus providing a novel therapeutic application for hUCMSCs in acute kidney injury [190]. 
Interleukin-12p40 (IL-12p40) homodimer is an antagonist of two potent pro-inflammatory cytokines IL-12 and IL-23 [188-190]. The latter are involved in inflammatory bowel disease, a chronic disorder of the digestive system that includes Crohn's disease and ulcerative colitis [191,192].

The effect of MSCs transduced by IL-12p40 has been investigated in dextran sulfate sodium salt-induced colitis, an animal model of bowel disease. Injection of Adv/IL-12p40 or MSC/IL-12p40 efficiently reduced colitis and tissue damage, thus increasing survival rate. IL$12 \mathrm{p} 40$ reduced both IFN- $\gamma$ and IL-17 production brought about by IL-12 and IL-23, respectively. This effect was more pronounced after MSCs/IL-12p40 than Adv/IL-12p40 administration [193].

\section{Interleukin-13, -27, -35}

Interleukin-13 (IL-13) is a pleiotropic cytokine very similar to IL-4 both in structure and function [194]. As mentioned above, it is secreted by Th2 lymphocytes and contributes to the etiology of allergic reactions. Differently from IL-4, T cells are generally unresponsive to IL13 due to the absence of IL-13Ra1 expression on their surface [195]. Allogeneic MSCs transduced with IL-13 have been transplanted to modulate allograft-specific immunity in a murine model. It has been shown that MSCs/IL-13 injection in muscle and in brain tissue prolongs allogeneic cell graft survival [196].

Interleukin-27 (IL-27) IL-27 and interleuking-35 (IL-35) are new members of the IL-12 family. Because of their properties, both of them could be used in the therapy of autoimmune diseases. Recently, in vitro works have demonstrated that transduction of hAT-MSC and hWJ-MSC with IL-27 and IL-35 does not alter naïve MSC properties [10,197].

\subsection{Enhancing MSC Immunostimulation}

MSCs have also been engineered with immunostimulating/proinflammatory cytokines mainly for the treatment of different kind of solid tumors. In the following section we summarize the results obtained by using the cytokines shown in Table 3 .

\section{Interferon- $\beta$}

Interferon- $\beta$ (IFN- $\beta$ ) is a pleiotropic cytokine with a wide range of biological activities such as regulation of cell proliferation, innate and adaptive immunity, hematopoiesis, angiogenesis, 
and yet other functions. Most importantly, it can promote tumor regression [198,199]. In 2002, Studeny used IFN- $\beta$-transduced hBM-MSCs to treat mice bearing human melanoma. He demonstrated for the first time that MSCs were integrated into the tumor and released high levels of IFN- $\beta$ in situ. Besides, hBM-MSCs/IFN- $\beta$ inhibited melanoma growth both in vitro and in vivo [8]. This study can be considered a ground-breaker in the field of MSC-based tumor-targeted gene therapy, and opened the way to many others studies where MSCs engineered with different proinflammatory citokines have been used to suppress solid tumors in animal models.

\section{Interleukin-2}

Interleukin-2 (IL-2) is secreted by CD4+ and CD8+ T lymphocytes and NK cells and is essential for T-cell proliferation. It is considered a proinflammatory cytokine because it can foster expansion of NK cells, CD8+ T cells and T-regs. Because of its immunostimulating properties, IL-2 has been tested in immunotherapy against several metastatic tumors. It was demonstrated that systemic administration of high doses of recombinant IL-2 in humans caused regression of metastatic melanoma, kidney cancer and non-Hodgkin's lymphoma [200]; therefore, IL-2 was approved for the treatment of metastatic renal cell carcinoma and melanoma by FDA [201-203].

To enhance the antitumorigenic effect of IL-2, rBM-MSCs engineered with IL-2 were tested in a rat model of glioma. Intracranial injection of such cells prolonged the survival of the recipients and reduced tumor mass to a greater extent than naïve rBM-MSCs [106].

\section{Interleukin-12}

Interleukin (IL-12) is a powerful activator of NK cells and macrophages. It also skews cellular immune responses towards a Th1 response and is produced by DCs and macrophages in response to activation [204,205]. IL-12 inhibits tumor growth and prolonges survival of different tumor-bearing animals [206,207]. Exogenous IL-12 administrated in phase-I and II clinical trials for cancer therapy, induced high levels of IFN- $\gamma$ and increased susceptibility of tumor cells to cytotoxic T lymphocytes. For this reason, it is now considered the main antitumoral cytokine [208-210].

BM-MSCs engineered with IL-12 were tested in experimental mouse models of melanoma, breast tumor, and hepatoma. Results showed that intravenous injection of BM-MSCs/IL-12 
markedly reduced progression of metastases both in midway and late tumor stages, with no significant toxicity. The effect observed with BM-MSCs/IL-12 was 10-fold higher than the one produced by Adv/IL-12 administration; in addition, the latter failed to favour regression of end-stage tumors [211]. Again, BM-MSCs/IL12 were able to migrate into the tumor site where they became part of the tumor architecture and released high level of IL-12 thus stimulating the immune response inside the tumor.

In another study, hBM-MSCs engineered with mIL-12 were tested in a mouse xenograft model of renal cell carcinoma. Systemic administration of hBM-MSC/mIL-12 reduced renal cell carcinoma growth and significantly prolonged mouse survival. Intra-tumor IFN- $\gamma$ levels were significantly higher after hBM-MSC/mIL-12 administration, thus suggesting that IFN- $\gamma$ plays a key role in tumor regression. Furthermore, the observed anti-tumor effect of hBMMSC/mIL-12 was mediated by NK cells [212]. In agreement with these results, it was also shown that mBM-MSCs/mIL-12 were also effective in the treatment of Ewing's sarcoma [213].

hUC-MSCs/IL-12 were evaluated in the SKOV3 experimental model of ovarian cancer. In vitro, the supernatant of IL-12-engineered hUC-MSCs was able to significantly inhibit proliferation of SKOV3 cells and trigger cellular apoptosis. In vivo, hUC-MSCs/IL-12 inibited tumor growth in a nude mouse model [214].

More recently, a modified form of IL-12 (IL12-M) has been used to transduce rBM-MSCs. IL-12M was obtained by N-glycosylation of IL-12 at Asn220. This change reduces secretion of the p40 subunit and enhances antigen-specific T-cell responses, without altering IFN- $\gamma$ secretion and IL-12 receptor binding affinity [215]. The effect of rBM-MSCs/IL-12M after intratumoral, intravenous and subcutaneous administration was evaluated in two experimental models of melanoma and cervical cancer. Pronounced regression of tumors was observed, especially after following intratumoral injection, suggesting that this route of administration has great relevance in therapy. rBM-MSCs/IL-12M were more efficient than either Adv-IL [216]. In a different study, in vitro work suggested the ability of AT-MSC transduced with LV/IL-12 to reduce lung adenocarcinoma ability of migration and invasion [217].

Taken together, the results from these studies suggest that IL-12-engineered MSC are attracted by several tumor microenvironments, where they cause release of release high levels of IFN- $\gamma$ triggering a tumor-specific T-cell response. The antitumor effect is stronger than with IL-12 delivered by Adv vectors and the toxicity is significantly lower. 


\section{Interleukin-15}

Interleukin-15 (IL-15) is functionally similar to IL-2 but does not stimulate T-reg proliferation. However, it does promote long-lasting antitumor T-cell immunity [217-220]. Because IL-15 administration has shown antitumor effects in many animal models and in human clinical trials [221,222], the effect of hUCB-MSCs transduced with mIL-15 was investigated in an experimental model of pancreatic adenocarcinoma, highly resistant to chemotherapy. The results showed that UCB-MSCs/mIL-15, systemically infused into syngeneic mice bearing Pan02 pancreatic tumors were able to migrate into the tumor site, where the secretion of IL-15 fostered activity by both NK and CD8+T cells, thus inhibiting tumor growth. Interestingly, mice treated with UCB-MSCs/IL-15 became resistant to Pan02 pancreatic tumor rechallenge, inferring that MSCs/IL15 were able to augment long-term tumor-specific T-cell immunity [223].

\section{Interleukin-18}

Interleukin-18 (IL-18), also known as IFN- $\gamma$-inducing factor, is similar to IL-1 both in structure and functionality; it is able to stimulate innate immunity, Th1- and Th2-mediated responses and NK activity [224,225]. IL-18 is a potent antitumor cytokine, by inducing tumor cell apoptosis and inhibiting tumor angiogenesis [226].

IL-18 was shown to favour immune cell migration in gastric cancer and melanoma [227,228]. To test its effects on glioma, rBM-MSCs transduced with IL-18 have been tested in vitro and in vivo in a glioma-bearing rat model. It was shown that rBM-MSCs/IL-18 inhibited glioma growth and prolonged the survival of glioma-bearing rats. The study also showed that the antitumor effect of rBM-MSCs/IL-18 is carried out through the enhancement of T-cell cytotoxic activity [229]. Unfortunately, complete suppression of tumor growth could not be achieved; hence, to extend the efficacy of such treatment, rBM-MSCs were transduced with a bicistronic LV vector encoding IL-18 and IFN- $\beta$. In this case, inhibition of glioma growth was enhanced, demonstrating that IL-18 and IFN- $\beta$ act sinergistically [230].

Finally, the effect of hUC-MSCs/IL-18 was investigated in a model of breast cancer in vitro: engineered MSCs were able to suppress proliferation, migration and invasion of breast cancer cells $[231,232]$.

\section{Interleukin-21}


As an immunostimulating cytokine involved in $\mathrm{T}$ and NK cell activation, interleukin-21 (IL21) is also able to induce strong cell-mediated immune responses in anti-tumor vaccine approaches [233]. It has been tested as therapeutic agent in several animal models of cancer and in clinical trials, against tumors such as metastatic lymphoma, melanoma, ovarian cancer, and others [233,234].

More recently, Il-21-transduced hUC-MSCs (MSCs/IL21) were injected intratumorally in mice bearing SKOV3 ovarian cancer. Results showed that hUC-MSCs/IL-21 had potent antitumor effects mediated by IL-21 release and upregulation of NK activity through the IFN$\gamma$ and TNF- $\alpha$ secretion [235]. MSCs/IL-21 have also been used in the treatment of B-cell lymphoma: MSCs/IL-21 intravenous injected were able to delay tumor incidence and to improve survival through upregulation of NK and effector T cells [236].

\section{Interleukin-28}

Interleukin-28 (IL-28) belongs to the type III IFN family, together with IFN- $\lambda 1,-\lambda 2$ and $-\lambda 3$ (also known as IL-29), IL-28A and IL-28B [237,238]. It has been shown that type III IFNs can exert anti-proliferative activity and promote apoptosis in tumors such as lung and esophageal carcinoma [237,239]. Moreover, they proved to not only activate NKs and DCs, but also have anti-angiogenetic effects [238,240,241].

Recently, hBM-MSCs transduced with IL-28A were tested for their antitumoral activity in mice bearing human esophageal carcinoma or colon carcinoma. While naïve hBM-MSCs did not display any antiproliferative tumor effect, hBM-MSCs/IL-28A inhibited tumor growth and vascularization and stimulated NK activity to a greater extent than IL-28A alone [125].

\section{Tumor Necrosis Factor- $\alpha$}

Tumor necrosis factor- $\square$ (TNF- $\alpha$ ) has a pivotal role in the early immune response, it can activate both macrophages and neutrophils and is involved in the maturation and activation of DCs. It is also a critical cytokine for promoting Th17 cell differentiation. TNF- $\alpha$ and CD40 ligand (CD40L) have been used to transduce MSCs and the immune-modulatory effects of engineered MSCs have been investigated in vitro and in vivo in animal models of human breast cancer [242].

In vitro results showed that $\mathrm{MSC} / \mathrm{TNF}-\alpha / \mathrm{CD} 40 \mathrm{~L}$ induced proinflammatory responses 
through maturation of DCs, increase of TNF- $\alpha$, IL-6, and IL-12 levels and reduction of TGF$\beta$, IL-4, and IL-10 levels, suggesting that they were able to cause a shift toward Th1 profile [242]. These results have also been confirmed in vivo, where stimulation of Th1 cytokines and inhibition of the Th2 pattern reduced tumor progression to a greater extent than naïve MSCs [242].

From all these studies, it is evident that MSCs engineered with immunostimulating cytokines are more powerful tools for cancer therapy than cytokines alone. All results underlined the ability of MSCs to migrate into tumor sites and stimulate release of proinflammatory cytokines, which, in turn, prompted a potent cytotoxic effect against cancer cells without affecting healthy tissues. It is to emphasize that route of administration of engineered MSCs seemed more important than the type of cytokine transduced to obtain the best result: indeed, intratumoral injection increased their efficacy, while little difference was observed with different cytokines. In addition, MSCs transduced with combined cytokines greatly enhanced the results most likely due to the synergistic effect of cytokines.

An interesting question arising from all these studies concerns the ability of immunoenhanced MSCs to keep releasing immunosuppressive factors, such as TGF- $\beta$, IDO, PEG-2 and many others. Could transduction modify the immunosuppressive profile of MSCs? Since it has been shown that transduction of MSCs with viral vectors did not affect MSC properties, we can speculate that their ability should not be modified. Nevertheless, the release of proinflammatory cytokines from MSCs could inhibit the production of anti-inflammatory ones in an autocrine fashion, and the balance between the pro/anti inflammatory profile of MSCs could be tipped in favor of the pro-inflammatory one also in the presence of pro-inflammatory stimuli. This point was not investigated in the works examined, and the question is open and deserves further insight.

Stability and duration over time of the pro-inflammatory cytokines production depend on the method of transduction used. As said above, LVs guarantee a long-lasting transgene expression compared to the ADV and AAV because of the integration of the transgene in the genome. However, most of the work revised in this review does not address the issue of duration expressly.

\section{Future outlook}

One of the main goals of regenerative and personalized medicine is the development of cellular therapies free of side effects, and devoid of ethical concerns. MSCs were found to be 
suitable and promising candidates, as demonstrated by the remarkable results obtained in numerous clinical trials. Although the vectors alone are being used in various clinical settings and preclinical studies showed that MSC transduction is safe and can enhance therapeutic potential compared to naïve MSCs, no clinical trials have yet been performed with engineered MSCs.

Large-scale application of engineered MSCs for cell therapy requires a high number of cells readily available; this obstacle could be overcome by implementation of small-scale bioreactors that have proved adeguate to obtain large numbers of clinical grade MSCs [243]. Another new promising source of MSCs are inducible pluripotent stem cells that can be reprogrammed into MSCs, making it possible to derive autologous MSCs from uninvasive biopsies (e.g. skin biopsy)[244]. This derivation also solves troubles with the aged patient, who carries BM-MSCs with significantly reduced survival and differentiation potential: in contrast, using human iPSCs can generate indefinitely fresh MSCs. The only caveat seems their reduced adipogenic differentiation [245]. In addition, small-scale bioreactors have also proved effective at expanding pluripotent stem cells [246], making clinical trials with inducible pluripotent stem cells -derived MSC accessible to small laboratories.

Viral vector manufacturing is quickly moving from plates to bioreactors, with advantages in terms of costs, standardization, and biosafety [247]. This shift will facilitate genetic engineering to move from bench to bedside. As new generation, safer viral vectors have come of age as a therapeutic tool, with, as mentioned, the European Medicines Agency approving the first gene therapy using an AAV vector to treat lipoprotein lipase deficiency (Glybera $\left.{ }^{\circledR}\right)$ in 2012. Furthermore, recent data from three clinical trials of gene therapy for hemophilia B are very encouraging [248]. These examples and many more undergoing gene therapy trials are increasing expectations of gene therapy at bedside.

However, with the first gene therapy now licensed and priced at around US\$1 million per patient, cost and uncertain funding mechanisms present a potential barrier to patient access.

Mixing advances in gene transfer and manipulation (e. g. gene editing) with advances in pluripotent stem cell reprogramming (e.g. non-integrative reprogramming and bench bioreactors), and large-scale production and cost/reimbursement optimization will likely increase access to MSC therapeutics in the coming decade.

[249-253]

\section{Aknowledgements}


P.Q. is supported by Fondazione ARPA (www.fondazionearpa.it), D.F. acknowledges funds from Italian Society of Hematology (SIE) and Italian League against Leukemia (AIL).

\section{Author Disclosure Statement}

The authors have no commercial, proprietary or financial interest in the products or companies described in this article. 


\section{Reference}

1. Friedenstein AJ, UF Deriglasova, NN Kulagina, AF Panasuk, SF Rudakowa, EA Luriá and IA Ruadkow (1974). Precursors for fibroblasts in different populations of hematopoietic cells as detected by the in vitro colony assay method. Exp Hematol 2: 83-92.

2. Caplan AI (1991). Mesenchymal stem cells. J Orthop Res Off Publ Orthop Res Soc 9: 641-650.

3. Bruder SP, N Jaiswal and SE Haynesworth (1997). Growth kinetics, self-renewal, and the osteogenic potential of purified human mesenchymal stem cells during extensive subcultivation and following cryopreservation. J Cell Biochem 64: 278-294.

4. Horwitz EM, K Le Blanc, M Dominici, I Mueller, I Slaper-Cortenbach, FC Marini, RJ Deans, DS Krause, A Keating and International Society for Cellular Therapy (2005). Clarification of the nomenclature for MSC: The International Society for Cellular Therapy position statement. Cytotherapy 7: 393-395.

5. Caplan AI (2015). Adult Mesenchymal Stem Cells: When, Where, and How. Stem Cells Int 2015: 628767.

6. Bernardo ME and WE Fibbe (2013). Mesenchymal stromal cells: sensors and switchers of inflammation. Cell Stem Cell 13: 392-402.

7. Le Blanc K and D Mougiakakos (2012). Multipotent mesenchymal stromal cells and the innate immune system. Nat Rev Immunol 12: 383-396.

8. Studeny M, FC Marini, RE Champlin, C Zompetta, IJ Fidler and M Andreeff (2002). Bone marrow-derived mesenchymal stem cells as vehicles for interferon-beta delivery into tumors. Cancer Res 62: 3603-3608.

9. Quaranta P, D Focosi, M Di Iesu, C Cursi, A Zucca, M Curcio, S Lapi, L Boldrini, G Stampacchia, A Paolicchi, F Scatena, G Freer and M Pistello (2016). Human Wharton's jelly-derived mesenchymal stromal cells engineered to secrete Epstein-Barr virus interleukin-10 show enhanced immunosuppressive properties. Cytotherapy 18: 205-218.

10. Amari A, M Ebtekar, SM Moazzeni, M Soleimani, L Mohammadi Amirabad, MT Tahoori and M Massumi (2015). In Vitro Generation of IL-35-expressing Human Wharton's Jelly-derived Mesenchymal Stem Cells 
Using Lentiviral Vector. Iran J Allergy Asthma Immunol 14: 416-426.

11. McMahon JM, S Conroy, M Lyons, U Greiser, C O'shea, P Strappe, L Howard, M Murphy, F Barry and T O’Brien (2006). Gene transfer into rat mesenchymal stem cells: a comparative study of viral and nonviral vectors. Stem Cells Dev 15: 87-96.

12. Pittenger MF, AM Mackay, SC Beck, RK Jaiswal, R Douglas, JD Mosca, MA Moorman, DW Simonetti, S Craig and DR Marshak (1999). Multilineage potential of adult human mesenchymal stem cells. Science 284: $143-147$.

13. Simmons PJ and B Torok-Storb (1991). Identification of stromal cell precursors in human bone marrow by a novel monoclonal antibody, STRO-1. Blood 78: 55-62.

14. Da Silva Meirelles L, PC Chagastelles and NB Nardi (2006). Mesenchymal stem cells reside in virtually all post-natal organs and tissues. J Cell Sci 119: 2204-2213.

15. Kern S, H Eichler, J Stoeve, H Klüter and K Bieback (2006). Comparative analysis of mesenchymal stem cells from bone marrow, umbilical cord blood, or adipose tissue. Stem Cells Dayt Ohio 24: 1294-1301.

16. Zuk PA, M Zhu, P Ashjian, DA De Ugarte, JI Huang, H Mizuno, ZC Alfonso, JK Fraser, P Benhaim and MH Hedrick (2002). Human adipose tissue is a source of multipotent stem cells. Mol Biol Cell 13: 4279-4295.

17. Krampera M, S Sartoris, F Liotta, A Pasini, R Angeli, L Cosmi, A Andreini, F Mosna, B Bonetti, E Rebellato, MG Testi, F Frosali, G Pizzolo, G Tridente, E Maggi, S Romagnani and F Annunziato (2007). Immune regulation by mesenchymal stem cells derived from adult spleen and thymus. Stem Cells Dev 16: 797810.

18. Roufosse CA, NC Direkze, WR Otto and NA Wright (2004). Circulating mesenchymal stem cells. Int J Biochem Cell Biol 36: 585-597.

19. In 't Anker PS, SA Scherjon, C Kleijburg-van der Keur, GMJS de Groot-Swings, FHJ Claas, WE Fibbe and HHH Kanhai (2004). Isolation of mesenchymal stem cells of fetal or maternal origin from human placenta. Stem Cells Dayt Ohio 22: 1338-1345. 
20. Erices A, P Conget and JJ Minguell (2000). Mesenchymal progenitor cells in human umbilical cord blood. Br J Haematol 109: 235-242.

21. Troyer DL and ML Weiss (2008). Wharton's jelly-derived cells are a primitive stromal cell population. Stem Cells Dayt Ohio 26: 591-599.

22. Wang H-S, S-C Hung, S-T Peng, C-C Huang, H-M Wei, Y-J Guo, Y-S Fu, M-C Lai and C-C Chen (2004). Mesenchymal stem cells in the Wharton's jelly of the human umbilical cord. Stem Cells Dayt Ohio 22: 13301337.

23. Bortolotti F, L Ukovich, V Razban, V Martinelli, G Ruozi, B Pelos, F Dore, M Giacca and S Zacchigna (2015). In vivo therapeutic potential of mesenchymal stromal cells depends on the source and the isolation procedure. Stem Cell Rep 4: 332-339.

24. Mattar P and K Bieback (2015). Comparing the Immunomodulatory Properties of Bone Marrow, Adipose Tissue, and Birth-Associated Tissue Mesenchymal Stromal Cells. Front Immunol 6: 560.

25. Fraser JK, I Wulur, Z Alfonso and MH Hedrick (2006). Fat tissue: an underappreciated source of stem cells for biotechnology. Trends Biotechnol 24: 150-154.

26. Vieira NM, V Brandalise, E Zucconi, M Secco, BE Strauss and M Zatz (2010). Isolation, characterization, and differentiation potential of canine adipose-derived stem cells. Cell Transplant 19: 279-289.

27. Schimke MM, S Marozin and G Lepperdinger (2015). Patient-Specific Age: The Other Side of the Coin in Advanced Mesenchymal Stem Cell Therapy. Front Physiol 6: 362.

28. Dominici M, K Le Blanc, I Mueller, I Slaper-Cortenbach, F Marini, D Krause, R Deans, A Keating, D Prockop and E Horwitz (2006). Minimal criteria for defining multipotent mesenchymal stromal cells. The International Society for Cellular Therapy position statement. Cytotherapy 8: 315-317.

29. Tropel P, D Noël, N Platet, P Legrand, A-L Benabid and F Berger (2004). Isolation and characterisation of mesenchymal stem cells from adult mouse bone marrow. Exp Cell Res 295: 395-406.

30. González-Cruz RD, VC Fonseca and EM Darling (2012). Cellular mechanical properties reflect the 
differentiation potential of adipose-derived mesenchymal stem cells. Proc Natl Acad Sci U S A 109: E15231529.

31. Karagianni M, I Brinkmann, S Kinzebach, M Grassl, C Weiss, P Bugert and K Bieback (2013). A comparative analysis of the adipogenic potential in human mesenchymal stromal cells from cord blood and other sources. Cytotherapy 15: 76-88.

32. Reinisch A, N Etchart, D Thomas, NA Hofmann, M Fruehwirth, S Sinha, CK Chan, K Senarath-Yapa, E-Y Seo, T Wearda, UF Hartwig, C Beham-Schmid, S Trajanoski, Q Lin, W Wagner, C Dullin, F Alves, M Andreeff, IL Weissman, MT Longaker, K Schallmoser, R Majeti and D Strunk (2015). Epigenetic and in vivo comparison of diverse MSC sources reveals an endochondral signature for human hematopoietic niche formation. Blood 125: $249-260$.

33. Deans RJ and AB Moseley (2000). Mesenchymal stem cells: biology and potential clinical uses. Exp Hematol 28: 875-884.

34. Sacchetti B, A Funari, S Michienzi, S Di Cesare, S Piersanti, I Saggio, E Tagliafico, S Ferrari, PG Robey, M Riminucci and P Bianco (2007). Self-renewing osteoprogenitors in bone marrow sinusoids can organize a hematopoietic microenvironment. Cell 131: 324-336.

35. Méndez-Ferrer S, TV Michurina, F Ferraro, AR Mazloom, BD Macarthur, SA Lira, DT Scadden, A Ma'ayan, GN Enikolopov and PS Frenette (2010). Mesenchymal and haematopoietic stem cells form a unique bone marrow niche. Nature 466: 829-834.

36. Crisan M, S Yap, L Casteilla, C-W Chen, M Corselli, TS Park, G Andriolo, B Sun, B Zheng, L Zhang, C Norotte, P-N Teng, J Traas, R Schugar, BM Deasy, S Badylak, H-J Buhring, J-P Giacobino, L Lazzari, J Huard and B Péault (2008). A perivascular origin for mesenchymal stem cells in multiple human organs. Cell Stem Cell 3: $301-313$.

37. Najar M, G Raicevic, HI Boufker, H Fayyad Kazan, C De Bruyn, N Meuleman, D Bron, M Toungouz and L Lagneaux (2010). Mesenchymal stromal cells use PGE2 to modulate activation and proliferation of lymphocyte subsets: Combined comparison of adipose tissue, Wharton's Jelly and bone marrow sources. Cell Immunol 264: 
$171-179$.

38. Krampera M, J Galipeau, Y Shi, K Tarte, L Sensebe and MSC Committee of the International Society for Cellular Therapy (ISCT) (2013). Immunological characterization of multipotent mesenchymal stromal cells--The International Society for Cellular Therapy (ISCT) working proposal. Cytotherapy 15: 1054-1061.

39. Aggarwal S and MF Pittenger (2005). Human mesenchymal stem cells modulate allogeneic immune cell responses. Blood 105: 1815-1822.

40. Nauta AJ, AB Kruisselbrink, E Lurvink, R Willemze and WE Fibbe (2006). Mesenchymal stem cells inhibit generation and function of both CD34+-derived and monocyte-derived dendritic cells. J Immunol Baltim Md 1950 177: 2080-2087.

41. Glennie S, I Soeiro, PJ Dyson, EW-F Lam and F Dazzi (2005). Bone marrow mesenchymal stem cells induce division arrest anergy of activated T cells. Blood 105: 2821-2827.

42. Corcione A, F Benvenuto, E Ferretti, D Giunti, V Cappiello, F Cazzanti, M Risso, F Gualandi, GL Mancardi, V Pistoia and A Uccelli (2006). Human mesenchymal stem cells modulate B-cell functions. Blood 107: 367372.

43. Najar M, G Raicevic, H Id Boufker, B Stamatopoulos, C De Bruyn, N Meuleman, D Bron, M Toungouz and L Lagneaux (2010). Modulated expression of adhesion molecules and galectin-1: role during mesenchymal stromal cell immunoregulatory functions. Exp Hematol 38: 922-932.

44. Patel SA, L Sherman, J Munoz and P Rameshwar (2008). Immunological properties of mesenchymal stem cells and clinical implications. Arch Immunol Ther Exp (Warsz) 56: 1-8.

45. Consentius C, P Reinke and H-D Volk (2015). Immunogenicity of allogeneic mesenchymal stromal cells: what has been seen in vitro and in vivo? Regen Med 10: 305-315.

46. Moll G, A Hult, L von Bahr, JJ Alm, N Heldring, OA Hamad, L Stenbeck-Funke, S Larsson, Y Teramura, H Roelofs, B Nilsson, WE Fibbe, ML Olsson and K Le Blanc (2014). Do ABO blood group antigens hamper the therapeutic efficacy of mesenchymal stromal cells? PloS One 9: e85040. 
47. Fontaine MJ, H Shih, R Schäfer and MF Pittenger (2016). Unraveling the Mesenchymal Stromal Cells' Paracrine Immunomodulatory Effects. Transfus Med Rev 30: 37-43.

48. Ren G, L Zhang, X Zhao, G Xu, Y Zhang, AI Roberts, RC Zhao and Y Shi (2008). Mesenchymal stem cellmediated immunosuppression occurs via concerted action of chemokines and nitric oxide. Cell Stem Cell 2: $141-150$.

49. Meisel R, A Zibert, M Laryea, U Göbel, W Däubener and D Dilloo (2004). Human bone marrow stromal cells inhibit allogeneic T-cell responses by indoleamine 2,3-dioxygenase-mediated tryptophan degradation. Blood 103: 4619-4621.

50. Zappia E, S Casazza, E Pedemonte, F Benvenuto, I Bonanni, E Gerdoni, D Giunti, A Ceravolo, F Cazzanti, F Frassoni, G Mancardi and A Uccelli (2005). Mesenchymal stem cells ameliorate experimental autoimmune encephalomyelitis inducing T-cell anergy. Blood 106: 1755-1761.

51. Nemeth K, A Keane-Myers, JM Brown, DD Metcalfe, JD Gorham, JD Gorham, VG Bundoc, VG Bundoc, MG Hodges, I Jelinek, S Madala, S Karpati and E Mezey (2010). Bone marrow stromal cells use TGF-beta to suppress allergic responses in a mouse model of ragweed-induced asthma. Proc Natl Acad Sci U S A 107: 56525657.

52. Madec AM, R Mallone, G Afonso, E Abou Mrad, A Mesnier, A Eljaafari and C Thivolet (2009). Mesenchymal stem cells protect NOD mice from diabetes by inducing regulatory $\mathrm{T}$ cells. Diabetologia 52: 1391-1399.

53. Le Blanc K and LC Davies (2015). Mesenchymal stromal cells and the innate immune response. Immunol Lett 168: 140-146.

54. Chiossone L, R Conte, GM Spaggiari, M Serra, C Romei, F Bellora, F Becchetti, A Andaloro, L Moretta and C Bottino (2016). Mesenchymal stromal cells induce peculiar alternatively activated macrophages capable of dampening both innate and adaptive immune responses. Stem Cells Dayt Ohio.

55. Le Blanc K, I Rasmusson, B Sundberg, C Götherström, M Hassan, M Uzunel and O Ringdén (2004). Treatment of severe acute graft-versus-host disease with third party haploidentical mesenchymal stem cells. 
Lancet 363: 1439-1441.

56. Cahn J-Y, JP Klein, SJ Lee, N Milpied, D Blaise, JH Antin, V Leblond, N Ifrah, J-P Jouet, F Loberiza, O Ringden, AJ Barrett, MM Horowitz, G Socié, Société Française de Greffe de Moëlle et Thérapie Cellulaire, Dana Farber Cancer Institute and International Bone Marrow Transplant Registry (2005). Prospective evaluation of 2 acute graft-versus-host (GVHD) grading systems: a joint Société Française de Greffe de Moëlle et Thérapie Cellulaire (SFGM-TC), Dana Farber Cancer Institute (DFCI), and International Bone Marrow Transplant Registry (IBMTR) prospective study. Blood 106: 1495-1500.

57. Le Blanc K, F Frassoni, L Ball, F Locatelli, H Roelofs, I Lewis, E Lanino, B Sundberg, ME Bernardo, M Remberger, G Dini, RM Egeler, A Bacigalupo, W Fibbe, O Ringdén and Developmental Committee of the European Group for Blood and Marrow Transplantation (2008). Mesenchymal stem cells for treatment of steroid-resistant, severe, acute graft-versus-host disease: a phase II study. Lancet 371: 1579-1586.

58. Prasad VK, KG Lucas, GI Kleiner, JAM Talano, D Jacobsohn, G Broadwater, R Monroy and J Kurtzberg (2011). Efficacy and safety of ex vivo cultured adult human mesenchymal stem cells (Prochymal ${ }^{\mathrm{TM}}$ ) in pediatric patients with severe refractory acute graft-versus-host disease in a compassionate use study. Biol Blood Marrow Transplant J Am Soc Blood Marrow Transplant 17: 534-541.

59. Zhou H, M Guo, C Bian, Z Sun, Z Yang, Y Zeng, H Ai and RC Zhao (2010). Efficacy of bone marrowderived mesenchymal stem cells in the treatment of sclerodermatous chronic graft-versus-host disease: clinical report. Biol Blood Marrow Transplant J Am Soc Blood Marrow Transplant 16: 403-412.

60. Weng JY, X Du, SX Geng, YW Peng, Z Wang, ZS Lu, SJ Wu, CW Luo, R Guo, W Ling, CX Deng, PJ Liao and AP Xiang (2010). Mesenchymal stem cell as salvage treatment for refractory chronic GVHD. Bone Marrow Transplant 45: 1732-1740.

61. Eun HM, CY Pak, CJ Kim, RG McArthur and JW Yoon (1987). Role of cyclosporin A in macromolecular synthesis of beta-cells. Diabetes 36: 952-958.

62. Gillison SL, ST Bartlett and DL Curry (1991). Inhibition by cyclosporine of insulin secretion--a beta cellspecific alteration of islet tissue function. Transplantation 52: 890-895. 
63. Bamoulid J, O Staeck, F Halleck, D Khadzhynov, S Brakemeier, M Dürr and K Budde (2015). The need for minimization strategies: current problems of immunosuppression. Transpl Int Off J Eur Soc Organ Transplant 28: 891-900.

64. Liu H, S Liu, Y Li, X Wang, W Xue, G Ge and X Luo (2012). The role of SDF-1-CXCR4/CXCR7 axis in the therapeutic effects of hypoxia-preconditioned mesenchymal stem cells for renal ischemia/reperfusion injury. PloS One 7: e34608.

65. Casiraghi F, N Azzollini, P Cassis, B Imberti, M Morigi, D Cugini, RA Cavinato, M Todeschini, S Solini, A Sonzogni, N Perico, G Remuzzi and M Noris (2008). Pretransplant infusion of mesenchymal stem cells prolongs the survival of a semiallogeneic heart transplant through the generation of regulatory $\mathrm{T}$ cells. J Immunol Baltim Md 1950 181: 3933-3946.

66. Casiraghi F, N Azzollini, M Todeschini, RA Cavinato, P Cassis, S Solini, C Rota, M Morigi, M Introna, R Maranta, N Perico, G Remuzzi and M Noris (2012). Localization of mesenchymal stromal cells dictates their immune or proinflammatory effects in kidney transplantation. Am J Transplant Off J Am Soc Transplant Am Soc Transpl Surg 12: 2373-2383.

67. Ding Y, D Xu, G Feng, A Bushell, RJ Muschel and KJ Wood (2009). Mesenchymal stem cells prevent the rejection of fully allogenic islet grafts by the immunosuppressive activity of matrix metalloproteinase-2 and -9 . Diabetes 58: 1797-1806.

68. Bartholomew A, C Sturgeon, M Siatskas, K Ferrer, K McIntosh, S Patil, W Hardy, S Devine, D Ucker, R Deans, A Moseley and R Hoffman (2002). Mesenchymal stem cells suppress lymphocyte proliferation in vitro and prolong skin graft survival in vivo. Exp Hematol 30: 42-48.

69. Peng Y, M Ke, L Xu, L Liu, X Chen, W Xia, X Li, Z Chen, J Ma, D Liao, G Li, J Fang, G Pan and AP Xiang (2013). Donor-derived mesenchymal stem cells combined with low-dose tacrolimus prevent acute rejection after renal transplantation: a clinical pilot study. Transplantation 95: 161-168.

70. Tan J, W Wu, X Xu, L Liao, F Zheng, S Messinger, X Sun, J Chen, S Yang, J Cai, X Gao, A Pileggi and C Ricordi (2012). Induction therapy with autologous mesenchymal stem cells in living-related kidney transplants: a 
randomized controlled trial. JAMA 307: 1169-1177.

71. Longoni B, E Szilagyi, P Quaranta, GT Paoli, S Tripodi, S Urbani, B Mazzanti, B Rossi, R Fanci, GC Demontis, P Marzola, R Saccardi, M Cintorino and F Mosca (2010). Mesenchymal stem cells prevent acute rejection and prolong graft function in pancreatic islet transplantation. Diabetes Technol Ther 12: 435-446.

72. Lee RH, MJ Seo, RL Reger, JL Spees, AA Pulin, SD Olson and DJ Prockop (2006). Multipotent stromal cells from human marrow home to and promote repair of pancreatic islets and renal glomeruli in diabetic NOD/scid mice. Proc Natl Acad Sci U S A 103: 17438-17443.

73. Duijvestein M, ACW Vos, H Roelofs, ME Wildenberg, BB Wendrich, HW Verspaget, EMC KooyWinkelaar, F Koning, JJ Zwaginga, HH Fidder, AP Verhaar, WE Fibbe, GR van den Brink and DW Hommes (2010). Autologous bone marrow-derived mesenchymal stromal cell treatment for refractory luminal Crohn's disease: results of a phase I study. Gut 59: 1662-1669.

74. Garcia-Olmo D, D Herreros, I Pascual, JA Pascual, E Del-Valle, J Zorrilla, P De-La-Quintana, M GarciaArranz and M Pascual (2009). Expanded adipose-derived stem cells for the treatment of complex perianal fistula: a phase II clinical trial. Dis Colon Rectum 52: 79-86.

75. Sospedra M and R Martin (2016). Immunology of Multiple Sclerosis. Semin Neurol 36: 115-127.

76. Trapp BD, J Peterson, RM Ransohoff, R Rudick, S Mörk and L Bö (1998). Axonal transection in the lesions of multiple sclerosis. N Engl J Med 338: 278-285.

77. Geurts JJG, PK Stys, A Minagar, S Amor and R Zivadinov (2009). Gray matter pathology in (chronic) MS: modern views on an early observation. J Neurol Sci 282: 12-20.

78. Pluchino S, L Zanotti, E Brini, S Ferrari and G Martino (2009). Regeneration and repair in multiple sclerosis: the role of cell transplantation. Neurosci Lett 456: 101-106.

79. Mohyeddin Bonab M, S Yazdanbakhsh, J Lotfi, K Alimoghaddom, F Talebian, F Hooshmand, A Ghavamzadeh and B Nikbin (2007). Does mesenchymal stem cell therapy help multiple sclerosis patients? Report of a pilot study. Iran J Immunol IJI 4: 50-57. 
80. Yamout B, R Hourani, H Salti, W Barada, T El-Hajj, A Al-Kutoubi, A Herlopian, EK Baz, R Mahfouz, R Khalil-Hamdan, NMA Kreidieh, M El-Sabban and A Bazarbachi (2010). Bone marrow mesenchymal stem cell transplantation in patients with multiple sclerosis: a pilot study. J Neuroimmunol 227: 185-189.

81. Connick P, M Kolappan, C Crawley, DJ Webber, R Patani, AW Michell, M-Q Du, S-L Luan, DR Altmann, AJ Thompson, A Compston, MA Scott, DH Miller and S Chandran (2012). Autologous mesenchymal stem cells for the treatment of secondary progressive multiple sclerosis: an open-label phase 2 a proof-of-concept study. Lancet Neurol 11: 150-156.

82. Arbuckle MR, MT McClain, MV Rubertone, RH Scofield, GJ Dennis, JA James and JB Harley (2003). Development of autoantibodies before the clinical onset of systemic lupus erythematosus. N Engl J Med 349: $1526-1533$.

83. El-Badri NS, A Hakki, A Ferrari, R Shamekh and RA Good (2008). Autoimmune disease: is it a disorder of the microenvironment? Immunol Res 41: 79-86.

84. Gu Z, X Cao, J Jiang, L Li, Z Da, H Liu and C Cheng (2012). Upregulation of p16INK4A promotes cellular senescence of bone marrow-derived mesenchymal stem cells from systemic lupus erythematosus patients. Cell Signal 24: 2307-2314.

85. Suen J-L, H-T Li, Y-J Jong, B-L Chiang and J-H Yen (2009). Altered homeostasis of CD4(+) FoxP3(+) regulatory T-cell subpopulations in systemic lupus erythematosus. Immunology 127: 196-205.

86. Wang D, J Li, Y Zhang, M Zhang, J Chen, X Li, X Hu, S Jiang, S Shi and L Sun (2014). Umbilical cord mesenchymal stem cell transplantation in active and refractory systemic lupus erythematosus: a multicenter clinical study. Arthritis Res Ther 16: R79.

87. Schurgers E, H Kelchtermans, T Mitera, L Geboes and P Matthys (2010). Discrepancy between the in vitro and in vivo effects of murine mesenchymal stem cells on T-cell proliferation and collagen-induced arthritis. Arthritis Res Ther 12: R31.

88. Chen B, J Hu, L Liao, Z Sun, Q Han, Z Song and RC Zhao (2010). Flk-1+ mesenchymal stem cells aggravate collagen-induced arthritis by up-regulating interleukin-6. Clin Exp Immunol 159: 292-302. 
89. Tanaka Y (2015). Human mesenchymal stem cells as a tool for joint repair in rheumatoid arthritis. Clin Exp Rheumatol 33: S58-62.

90. Chen J, ZG Zhang, Y Li, L Wang, YX Xu, SC Gautam, M Lu, Z Zhu and M Chopp (2003). Intravenous administration of human bone marrow stromal cells induces angiogenesis in the ischemic boundary zone after stroke in rats. Circ Res 92: 692-699.

91. Li Y, J Chen, XG Chen, L Wang, SC Gautam, YX Xu, M Katakowski, LJ Zhang, M Lu, N Janakiraman and M Chopp (2002). Human marrow stromal cell therapy for stroke in rat: neurotrophins and functional recovery. Neurology 59: 514-523.

92. Cho K-S, H-K Park, H-Y Park, JS Jung, S-G Jeon, Y-K Kim and HJ Roh (2009). IFATS collection: Immunomodulatory effects of adipose tissue-derived stem cells in an allergic rhinitis mouse model. Stem Cells Dayt Ohio 27: 259-265.

93. Weiss DJ, JK Kolls, LA Ortiz, A Panoskaltsis-Mortari and DJ Prockop (2008). Stem cells and cell therapies in lung biology and lung diseases. Proc Am Thorac Soc 5: 637-667.

94. Németh K, A Leelahavanichkul, PST Yuen, B Mayer, A Parmelee, K Doi, PG Robey, K Leelahavanichkul, BH Koller, JM Brown, X Hu, I Jelinek, RA Star and E Mezey (2009). Bone marrow stromal cells attenuate sepsis via prostaglandin $\mathrm{E}(2)$-dependent reprogramming of host macrophages to increase their interleukin-10 production. Nat Med 15: 42-49.

95. Gonzalez-Rey E, P Anderson, MA González, L Rico, D Büscher and M Delgado (2009). Human adult stem cells derived from adipose tissue protect against experimental colitis and sepsis. Gut 58: 929-939.

96. Anderson P, L Souza-Moreira, M Morell, M Caro, F O’Valle, E Gonzalez-Rey and M Delgado (2013). Adipose-derived mesenchymal stromal cells induce immunomodulatory macrophages which protect from experimental colitis and sepsis. Gut 62: 1131-1141.

97. Mazzini L, I Ferrero, V Luparello, D Rustichelli, M Gunetti, K Mareschi, L Testa, A Stecco, R Tarletti, M Miglioretti, E Fava, N Nasuelli, C Cisari, M Massara, R Vercelli, GD Oggioni, A Carriero, R Cantello, F Monaco and F Fagioli (2010). Mesenchymal stem cell transplantation in amyotrophic lateral sclerosis: A Phase I 
clinical trial. Exp Neurol 223: 229-237.

98. Karussis D, C Karageorgiou, A Vaknin-Dembinsky, B Gowda-Kurkalli, JM Gomori, I Kassis, JWM Bulte, P Petrou, T Ben-Hur, O Abramsky and S Slavin (2010). Safety and immunological effects of mesenchymal stem cell transplantation in patients with multiple sclerosis and amyotrophic lateral sclerosis. Arch Neurol 67: $1187-$ 1194.

99. Henkel JS, DR Beers, S Wen, AL Rivera, KM Toennis, JE Appel, W Zhao, DH Moore, SZ Powell and SH Appel (2013). Regulatory T-lymphocytes mediate amyotrophic lateral sclerosis progression and survival. EMBO Mol Med 5: 64-79.

100. Brandau S, M Jakob, H Hemeda, K Bruderek, S Janeschik, F Bootz and S Lang (2010). Tissue-resident mesenchymal stem cells attract peripheral blood neutrophils and enhance their inflammatory activity in response to microbial challenge. J Leukoc Biol 88: 1005-1015.

101. Cassatella MA, F Mosna, A Micheletti, V Lisi, N Tamassia, C Cont, F Calzetti, M Pelletier, G Pizzolo and M Krampera (2011). Toll-like receptor-3-activated human mesenchymal stromal cells significantly prolong the survival and function of neutrophils. Stem Cells Dayt Ohio 29: 1001-1011.

102. Shi Y, J Su, AI Roberts, P Shou, AB Rabson and G Ren (2012). How mesenchymal stem cells interact with tissue immune responses. Trends Immunol 33: 136-143.

103. Li W, G Ren, Y Huang, J Su, Y Han, J Li, X Chen, K Cao, Q Chen, P Shou, L Zhang, Z-R Yuan, AI Roberts, S Shi, AD Le and Y Shi (2012). Mesenchymal stem cells: a double-edged sword in regulating immune responses. Cell Death Differ 19: 1505-1513.

104. Nakamizo A, F Marini, T Amano, A Khan, M Studeny, J Gumin, J Chen, S Hentschel, G Vecil, J Dembinski, M Andreeff and FF Lang (2005). Human bone marrow-derived mesenchymal stem cells in the treatment of gliomas. Cancer Res 65: 3307-3318.

105. Sato H, N Kuwashima, T Sakaida, M Hatano, JE Dusak, WK Fellows-Mayle, GD Papworth, SC Watkins, A Gambotto, IF Pollack and H Okada (2005). Epidermal growth factor receptor-transfected bone marrow stromal cells exhibit enhanced migratory response and therapeutic potential against murine brain tumors. Cancer 
Gene Ther 12: 757-768.

106. Nakamura K, Y Ito, Y Kawano, K Kurozumi, M Kobune, H Tsuda, A Bizen, O Honmou, Y Niitsu and H Hamada (2004). Antitumor effect of genetically engineered mesenchymal stem cells in a rat glioma model. Gene Ther 11: 1155-1164.

107. Hanahan D and RA Weinberg (2011). Hallmarks of cancer: the next generation. Cell 144: 646-674.

108. Rafii S and D Lyden (2003). Therapeutic stem and progenitor cell transplantation for organ vascularization and regeneration. Nat Med 9: 702-712.

109. Son B-R, LA Marquez-Curtis, M Kucia, M Wysoczynski, AR Turner, J Ratajczak, MZ Ratajczak and A Janowska-Wieczorek (2006). Migration of bone marrow and cord blood mesenchymal stem cells in vitro is regulated by stromal-derived factor-1-CXCR4 and hepatocyte growth factor-c-met axes and involves matrix metalloproteinases. Stem Cells Dayt Ohio 24: 1254-1264.

110. Azizi SA, D Stokes, BJ Augelli, C DiGirolamo and DJ Prockop (1998). Engraftment and migration of human bone marrow stromal cells implanted in the brains of albino rats--similarities to astrocyte grafts. Proc Natl Acad Sci U S A 95: 3908-3913.

111. Schwarz EJ, GM Alexander, DJ Prockop and SA Azizi (1999). Multipotential marrow stromal cells transduced to produce L-DOPA: engraftment in a rat model of Parkinson disease. Hum Gene Ther 10: 25392549.

112. Studeny M, FC Marini, JL Dembinski, C Zompetta, M Cabreira-Hansen, BN Bekele, RE Champlin and M Andreeff (2004). Mesenchymal stem cells: potential precursors for tumor stroma and targeted-delivery vehicles for anticancer agents. J Natl Cancer Inst 96: 1593-1603.

113. Grisendi G, R Bussolari, L Cafarelli, I Petak, V Rasini, E Veronesi, G De Santis, C Spano, M Tagliazzucchi, H Barti-Juhasz, L Scarabelli, F Bambi, A Frassoldati, G Rossi, C Casali, U Morandi, EM Horwitz, P Paolucci, P Conte and M Dominici (2010). Adipose-derived mesenchymal stem cells as stable source of tumor necrosis factor-related apoptosis-inducing ligand delivery for cancer therapy. Cancer Res 70: 37183729. 
114. Qiao L, Z Xu, T Zhao, Z Zhao, M Shi, RC Zhao, L Ye and X Zhang (2008). Suppression of tumorigenesis by human mesenchymal stem cells in a hepatoma model. Cell Res 18: 500-507.

115. Khakoo AY, S Pati, SA Anderson, W Reid, MF Elshal, II Rovira, AT Nguyen, D Malide, CA Combs, G Hall, J Zhang, M Raffeld, TB Rogers, W Stetler-Stevenson, JA Frank, M Reitz and T Finkel (2006). Human mesenchymal stem cells exert potent antitumorigenic effects in a model of Kaposi's sarcoma. J Exp Med 203: $1235-1247$.

116. Karnoub AE, AB Dash, AP Vo, A Sullivan, MW Brooks, GW Bell, AL Richardson, K Polyak, R Tubo and RA Weinberg (2007). Mesenchymal stem cells within tumour stroma promote breast cancer metastasis. Nature 449: 557-563.

117. Einhorn S and D Grander (1996). Why do so many cancer patients fail to respond to interferon therapy? J Interferon Cytokine Res Off J Int Soc Interferon Cytokine Res 16: 275-281.

118. Okada H and IF Pollack (2004). Cytokine gene therapy for malignant glioma. Expert Opin Biol Ther 4: $1609-1620$.

119. Jordan M and F Wurm (2004). Transfection of adherent and suspended cells by calcium phosphate. Methods San Diego Calif 33: 136-143.

120. Vannucci L, M Lai, F Chiuppesi, L Ceccherini-Nelli and M Pistello (2013). Viral vectors: a look back and ahead on gene transfer technology. New Microbiol 36: 1-22.

121. Muhammad AKMG, W Xiong, M Puntel, C Farrokhi, KM Kroeger, A Salem, L Lacayo, RN Pechnick, KR Kelson, D Palmer, P Ng, C Liu, PR Lowenstein and MG Castro (2012). Safety profile of gutless adenovirus vectors delivered into the normal brain parenchyma: implications for a glioma phase 1 clinical trial. Hum Gene Ther Methods 23: 271-284.

122. Kaufmann JK and DM Nettelbeck (2012). Virus chimeras for gene therapy, vaccination, and oncolysis: adenoviruses and beyond. Trends Mol Med 18: 365-376.

123. Kawabata K, F Sakurai, N Koizumi, T Hayakawa and H Mizuguchi (2006). Adenovirus vector-mediated 
gene transfer into stem cells. Mol Pharm 3: 95-103.

124. Belin MT and P Boulanger (1993). Involvement of cellular adhesion sequences in the attachment of adenovirus to the HeLa cell surface. J Gen Virol 74 ( Pt 8): 1485-1497.

125. Suzuki T, K Kawamura, Q Li, S Okamoto, Y Tada, K Tatsumi, H Shimada, K Hiroshima, N Yamaguchi and M Tagawa (2014). Mesenchymal stem cells are efficiently transduced with adenoviruses bearing type 35derived fibers and the transduced cells with the IL-28A gene produces cytotoxicity to lung carcinoma cells cocultured. BMC Cancer 14: 713.

126. Tsuda H, T Wada, Y Ito, H Uchida, H Dehari, K Nakamura, K Sasaki, M Kobune, T Yamashita and H Hamada (2003). Efficient BMP2 gene transfer and bone formation of mesenchymal stem cells by a fiber-mutant adenoviral vector. Mol Ther J Am Soc Gene Ther 7: 354-365.

127. Yu D, C Jin, M Ramachandran, J Xu, B Nilsson, O Korsgren, K Le Blanc, L Uhrbom, K Forsberg-Nilsson, B Westermark, R Adamson, N Maitland, X Fan and M Essand (2013). Adenovirus serotype 5 vectors with TatPTD modified hexon and serotype 35 fiber show greatly enhanced transduction capacity of primary cell cultures. PloS One 8: e54952.

128. Palmer GD, MJ Stoddart, E Gouze, J-N Gouze, SC Ghivizzani, RM Porter and CH Evans (2008). A simple, lanthanide-based method to enhance the transduction efficiency of adenovirus vectors. Gene Ther 15: 357-363.

129. Yao X, N Zhou, L Wan, X Su, Z Sun, H Mizuguchi, Y Yoshioka, S Nakagawa, RC Zhao and J-Q Gao (2014). Polyethyleneimine-coating enhances adenoviral transduction of mesenchymal stem cells. Biochem Biophys Res Commun 447: 383-387.

130. Kim SM, JY Lim, SI Park, CH Jeong, JH Oh, M Jeong, W Oh, S-H Park, Y-C Sung and S-S Jeun (2008). Gene therapy using TRAIL-secreting human umbilical cord blood-derived mesenchymal stem cells against intracranial glioma. Cancer Res 68: 9614-9623.

131. Stender S, M Murphy, T O’Brien, C Stengaard, M Ulrich-Vinther, K Søballe and F Barry (2007). Adenoassociated viral vector transduction of human mesenchymal stem cells. Eur Cell Mater 13: 93-99; discussion 99. 
132. Khan IF, RK Hirata and DW Russell (2011). AAV-mediated gene targeting methods for human cells. Nat Protoc 6: 482-501.

133. Locke M, JE Ussher, R Mistry, JA Taylor and PR Dunbar (2011). Transduction of human adipose-derived mesenchymal stem cells by recombinant adeno-associated virus vectors. Tissue Eng Part C Methods 17: 949959.

134. Cucchiarini M and H Madry (2014). Overexpression of human IGF-I via direct rAAV-mediated gene transfer improves the early repair of articular cartilage defects in vivo. Gene Ther 21: 811-819.

135. Gabriel N, R Samuel and GR Jayandharan (2015). Targeted delivery of AAV-transduced mesenchymal stromal cells to hepatic tissue for ex vivo gene therapy. J Tissue Eng Regen Med.

136. Tao K, J Frisch, A Rey-Rico, JK Venkatesan, G Schmitt, H Madry, J Lin and M Cucchiarini (2016). Cooverexpression of TGF- $\beta$ and SOX9 via rAAV gene transfer modulates the metabolic and chondrogenic activities of human bone marrow-derived mesenchymal stem cells. Stem Cell Res Ther 7: 20.

137. Zanotti L, R Angioni, B Calì, C Soldani, C Ploia, F Moalli, M Gargesha, G D’Amico, S Elliman, G Tedeschi, E Maffioli, A Negri, S Zacchigna, A Sarukhan, JV Stein and A Viola (2016). Mouse mesenchymal stem cells inhibit high endothelial cell activation and lymphocyte homing to lymph nodes by releasing TIMP-1. Leukemia 30: 1143-1154.

138. Naldini L, U Blömer, P Gallay, D Ory, R Mulligan, FH Gage, IM Verma and D Trono (1996). In vivo gene delivery and stable transduction of nondividing cells by a lentiviral vector. Science 272: 263-267.

139. Zhang X-Y, VF La Russa, L Bao, J Kolls, P Schwarzenberger and J Reiser (2002). Lentiviral vectors for sustained transgene expression in human bone marrow-derived stromal cells. Mol Ther J Am Soc Gene Ther 5: $555-565$.

140. Van Damme A, L Thorrez, L Ma, H Vandenburgh, J Eyckmans, F Dell'Accio, C De Bari, F Luyten, D Lillicrap, D Collen, T VandenDriessche and MKL Chuah (2006). Efficient lentiviral transduction and improved engraftment of human bone marrow mesenchymal cells. Stem Cells Dayt Ohio 24: 896-907. 
141. Meyerrose TE, M Roberts, KK Ohlemiller, CA Vogler, L Wirthlin, JA Nolta and MS Sands (2008). Lentiviral-transduced human mesenchymal stem cells persistently express therapeutic levels of enzyme in a xenotransplantation model of human disease. Stem Cells Dayt Ohio 26: 1713-1722.

142. Takada T, K Iida, T Awaji, K Itoh, R Takahashi, A Shibui, K Yoshida, S Sugano and G Tsujimoto (1997). Selective production of transgenic mice using green fluorescent protein as a marker. Nat Biotechnol 15: 458461.

143. Chung J-Y, F Mackay and F Alderuccio (2015). Efficient conditional gene expression following transplantation of retrovirally transduced bone marrow stem cells. J Immunol Methods 416: 183-188.

144. Guo ZS, Q Li, DL Bartlett, JY Yang and B Fang (2008). Gene transfer: the challenge of regulated gene expression. Trends Mol Med 14: 410-418.

145. Campan M, V Lionetti, GD Aquaro, F Forini, M Matteucci, L Vannucci, F Chiuppesi, C Di Cristofano, M Faggioni, M Maioli, L Barile, E Messina, M Lombardi, A Pucci, M Pistello and FA Recchia (2011). Ferritin as a reporter gene for in vivo tracking of stem cells by 1.5-T cardiac MRI in a rat model of myocardial infarction. Am J Physiol Heart Circ Physiol 300: H2238-2250.

146. Schett G, J-M Dayer and B Manger (2016). Interleukin-1 function and role in rheumatic disease. Nat Rev Rheumatol 12: 14-24.

147. Cohen I, P Rider, Y Carmi, A Braiman, S Dotan, MR White, E Voronov, MU Martin, CA Dinarello and RN Apte (2010). Differential release of chromatin-bound IL-1alpha discriminates between necrotic and apoptotic cell death by the ability to induce sterile inflammation. Proc Natl Acad Sci U S A 107: 2574-2579.

148. Dinarello CA (1996). Biologic basis for interleukin-1 in disease. Blood 87: 2095-2147.

149. Sekiyama KD, M Yoshiba and AW Thomson (1994). Circulating proinflammatory cytokines (IL-1 beta, TNF-alpha, and IL-6) and IL-1 receptor antagonist (IL-1Ra) in fulminant hepatic failure and acute hepatitis. Clin Exp Immunol 98: 71-77.

150. Dinarello CA (2000). The role of the interleukin-1-receptor antagonist in blocking inflammation mediated 
by interleukin-1. N Engl J Med 343: 732-734.

151. Campion GV, ME Lebsack, J Lookabaugh, G Gordon and M Catalano (1996). Dose-range and dosefrequency study of recombinant human interleukin-1 receptor antagonist in patients with rheumatoid arthritis. The IL-1Ra Arthritis Study Group. Arthritis Rheum 39: 1092-1101.

152. Prockop DJ and JY Oh (2012). Mesenchymal stem/stromal cells (MSCs): role as guardians of inflammation. Mol Ther J Am Soc Gene Ther 20: 14-20.

153. Ortiz LA, M Dutreil, C Fattman, AC Pandey, G Torres, K Go and DG Phinney (2007). Interleukin 1 receptor antagonist mediates the antiinflammatory and antifibrotic effect of mesenchymal stem cells during lung injury. Proc Natl Acad Sci U S A 104: 11002-11007.

154. Shi X-L, W Zhu, J-J Tan, J-Q Xiao, L Zhang, Q Xu, Z-L Ma and Y-T Ding (2013). Effect evaluation of interleukin-1 receptor antagonist nanoparticles for mesenchymal stem cell transplantation. World J Gastroenterol 19: 1984-1991.

155. Mundra V, H Wu and RI Mahato (2013). Genetically modified human bone marrow derived mesenchymal stem cells for improving the outcome of human islet transplantation. PloS One 8: e77591.

156. Wu H, W Lu and RI Mahato (2011). Mesenchymal stem cells as a gene delivery vehicle for successful islet transplantation. Pharm Res 28: 2098-2109.

157. Narang AS and RI Mahato (2006). Biological and biomaterial approaches for improved islet transplantation. Pharmacol Rev 58: 194-243.

158. Biarnés M, M Montolio, V Nacher, M Raurell, J Soler and E Montanya (2002). Beta-cell death and mass in syngeneically transplanted islets exposed to short- and long-term hyperglycemia. Diabetes 51: 66-72.

159. Ryan EA, BW Paty, PA Senior, D Bigam, E Alfadhli, NM Kneteman, JRT Lakey and AMJ Shapiro (2005). Five-year follow-up after clinical islet transplantation. Diabetes 54: 2060-2069.

160. Wehling N, GD Palmer, C Pilapil, F Liu, JW Wells, PE Müller, CH Evans and RM Porter (2009). Interleukin-1beta and tumor necrosis factor alpha inhibit chondrogenesis by human mesenchymal stem cells 
through NF-kappaB-dependent pathways. Arthritis Rheum 60: 801-812.

161. Glass KA, JM Link, JM Brunger, FT Moutos, CA Gersbach and F Guilak (2014). Tissue-engineered cartilage with inducible and tunable immunomodulatory properties. Biomaterials 35: 5921-5931.

162. Sang J-F, X-L Shi, B Han, X Huang, T Huang, H-Z Ren and Y-T Ding (2016). Combined mesenchymal stem cell transplantation and interleukin-1 receptor antagonism after partial hepatectomy. World J Gastroenterol 22: $4120-4135$.

163. Freer G (2016). Interleukin 10 in Antiviral Responses. Curr Immunol Rev 12: 20-26.

164. De Waal Malefyt R, J Abrams, B Bennett, CG Figdor and JE de Vries (1991). Interleukin 10(IL-10) inhibits cytokine synthesis by human monocytes: an autoregulatory role of IL-10 produced by monocytes. J Exp Med 174: $1209-1220$.

165. Zuo Z, C Wang, D Carpenter, Y Okada, E Nicolaidou, M Toyoda, A Trento and SC Jordan (2001). Prolongation of allograft survival with viral IL-10 transfection in a highly histoincompatible model of rat heart allograft rejection. Transplantation 71: 686-691.

166. Tashiro H, K Shinozaki, H Yahata, K Hayamizu, T Okimoto, H Tanji, Y Fudaba, H Yamamoto, X Fan, H Ito and T Asahara (2000). Prolongation of liver allograft survival after interleukin-10 gene transduction 24-48 hours before donation. Transplantation 70: 336-339.

167. Niu J, W Yue, Y Song, Y Zhang, X Qi, Z Wang, B Liu, H Shen and X Hu (2014). Prevention of acute liver allograft rejection by IL-10-engineered mesenchymal stem cells. Clin Exp Immunol 176: 473-484.

168. Li W, CS Kuhr, XX Zheng, K Carper, AW Thomson, JD Reyes and JD Perkins (2008). New insights into mechanisms of spontaneous liver transplant tolerance: the role of Foxp3-expressing CD25+CD4+ regulatory T cells. Am J Transplant Off J Am Soc Transplant Am Soc Transpl Surg 8: 1639-1651.

169. Wing K and S Sakaguchi (2010). Regulatory T cells exert checks and balances on self tolerance and autoimmunity. Nat Immunol 11: 7-13.

170. Amari A, M Ebtekar, SM Moazzeni, M Soleimani, LM Amirabad, MT Tahoori and M Massumi (2015). 
Investigation of immunomodulatory properties of Human Wharton's Jelly-derived Mesenchymal Stem Cells after lentiviral transduction. Cell Immunol 293: 59-66.

171. Ouyang P, K Rakus, SJ van Beurden, AH Westphal, AJ Davison, D Gatherer and AF Vanderplasschen (2014). IL-10 encoded by viruses: a remarkable example of independent acquisition of a cellular gene by viruses and its subsequent evolution in the viral genome. J Gen Virol 95: 245-262.

172. Gruffat H, F Kadjouf, B Mariamé and E Manet (2012). The Epstein-Barr virus BcRF1 gene product is a TBP-like protein with an essential role in late gene expression. J Virol 86: 6023-6032.

173. Kanai K, Y Satoh, H Yamanaka, A Kawaguchi, K Horie, K Sugata, Y Hoshikawa, T Sata and T Sairenji (2007). The vIL-10 gene of the Epstein-Barr virus (EBV) is conserved in a stable manner except for a few point mutations in various EBV isolates. Virus Genes 35: 563-569.

174. Pace L, C Pioli and G Doria (2005). IL-4 modulation of CD4+CD25+ T regulatory cell-mediated suppression. J Immunol Baltim Md 1950 174: 7645-7653.

175. Butti E, A Bergami, A Recchia, E Brambilla, U Del Carro, S Amadio, A Cattalini, M Esposito, A Stornaiuolo, G Comi, S Pluchino, F Mavilio, G Martino and R Furlan (2008). IL4 gene delivery to the CNS recruits regulatory $\mathrm{T}$ cells and induces clinical recovery in mouse models of multiple sclerosis. Gene Ther 15: $504-515$.

176. Aharoni R, D Teitelbaum, O Leitner, A Meshorer, M Sela and R Arnon (2000). Specific Th2 cells accumulate in the central nervous system of mice protected against experimental autoimmune encephalomyelitis by copolymer 1. Proc Natl Acad Sci U S A 97: 11472-11477.

177. Yang J-S, L-Y Xu, B-G Xiao, G Hedlund and H Link (2004). Laquinimod (ABR-215062) suppresses the development of experimental autoimmune encephalomyelitis, modulates the Th1/Th2 balance and induces the Th3 cytokine TGF-beta in Lewis rats. J Neuroimmunol 156: 3-9.

178. Racke MK, A Bonomo, DE Scott, B Cannella, A Levine, CS Raine, EM Shevach and M Röcken (1994). Cytokine-induced immune deviation as a therapy for inflammatory autoimmune disease. J Exp Med 180: 19611966. 
179. Garren H, PJ Ruiz, TA Watkins, P Fontoura, LT Nguyen, ER Estline, DL Hirschberg and L Steinman (2001). Combination of gene delivery and DNA vaccination to protect from and reverse Th1 autoimmune disease via deviation to the Th2 pathway. Immunity 15: 15-22.

180. Furlan R, PL Poliani, PC Marconi, A Bergami, F Ruffini, L Adorini, JC Glorioso, G Comi and G Martino (2001). Central nervous system gene therapy with interleukin-4 inhibits progression of ongoing relapsingremitting autoimmune encephalomyelitis in Biozzi AB/H mice. Gene Ther 8: 13-19.

181. Poliani PL, H Brok, R Furlan, F Ruffini, A Bergami, G Desina, PC Marconi, M Rovaris, A Uccelli, JC Glorioso, G Penna, L Adorini, G Comi, B 't Hart and G Martino (2001). Delivery to the central nervous system of a nonreplicative herpes simplex type 1 vector engineered with the interleukin 4 gene protects rhesus monkeys from hyperacute autoimmune encephalomyelitis. Hum Gene Ther 12: 905-920.

182. Payne NL, A Dantanarayana, G Sun, L Moussa, S Caine, C McDonald, D Herszfeld, CCA Bernard and C Siatskas (2012). Early intervention with gene-modified mesenchymal stem cells overexpressing interleukin-4 enhances anti-inflammatory responses and functional recovery in experimental autoimmune demyelination. Cell Adhes Migr 6: 179-189.

183. Tan C, X Gao, L Guo and H Huang (2014). Exogenous IL-4-expressing bone marrow mesenchymal stem cells for the treatment of autoimmune sensorineural hearing loss in a guinea pig model. BioMed Res Int 2014: 856019.

184. Bai L, DP Lennon, AI Caplan, A DeChant, J Hecker, J Kranso, A Zaremba and RH Miller (2012). Hepatocyte growth factor mediates mesenchymal stem cell-induced recovery in multiple sclerosis models. Nat Neurosci 15: 862-870.

185. Kuroiwa T, E Kakishita, T Hamano, Y Kataoka, Y Seto, N Iwata, Y Kaneda, K Matsumoto, T Nakamura, T Ueki, J Fujimoto and T Iwasaki (2001). Hepatocyte growth factor ameliorates acute graft-versus-host disease and promotes hematopoietic function. J Clin Invest 107: 1365-1373.

186. Di Nicola M, C Carlo-Stella, M Magni, M Milanesi, PD Longoni, P Matteucci, S Grisanti and AM Gianni (2002). Human bone marrow stromal cells suppress T-lymphocyte proliferation induced by cellular or 
nonspecific mitogenic stimuli. Blood 99: 3838-3843.

187. Nasef A, A Chapel, C Mazurier, S Bouchet, M Lopez, N Mathieu, L Sensebé, Y Zhang, N-C Gorin, D Thierry and L Fouillard (2007). Identification of IL-10 and TGF-beta transcripts involved in the inhibition of Tlymphocyte proliferation during cell contact with human mesenchymal stem cells. Gene Expr 13: 217-226.

188. Zhu J and Y Chen (2011). [Effect of human hepatocyte growth factor gene-modified bone marrow mesenchymal stem cells on immunological rejection after allograft liver transplantation in rats]. Zhongguo Xiu Fu Chong Jian Wai Ke Za Zhi Zhongguo Xiufu Chongjian Waike Zazhi Chin J Reparative Reconstr Surg 25: $871-876$.

189. Wang H, Y-F Yang, L Zhao, F-J Xiao, Q-W Zhang, M-L Wen, C-T Wu, R-Y Peng and L-S Wang (2013). Hepatocyte growth factor gene-modified mesenchymal stem cells reduce radiation-induced lung injury. Hum Gene Ther 24: 343-353.

190. Chen Y, H Qian, W Zhu, X Zhang, Y Yan, S Ye, X Peng, W Li and W Xu (2011). Hepatocyte growth factor modification promotes the amelioration effects of human umbilical cord mesenchymal stem cells on rat acute kidney injury. Stem Cells Dev 20: 103-113.

191. Elson CO, Y Cong, CT Weaver, TR Schoeb, TK McClanahan, RB Fick and RA Kastelein (2007). Monoclonal anti-interleukin 23 reverses active colitis in a T cell-mediated model in mice. Gastroenterology 132: 2359-2370.

192. Hue S, P Ahern, S Buonocore, MC Kullberg, DJ Cua, BS McKenzie, F Powrie and KJ Maloy (2006). Interleukin-23 drives innate and T cell-mediated intestinal inflammation. J Exp Med 203: 2473-2483.

193. Kim D-J, K-S Kim, M-Y Song, S-H Seo, S-J Kim, B-G Yang, M-H Jang and Y-C Sung (2012). Delivery of IL-12p40 ameliorates DSS-induced colitis by suppressing IL-17A expression and inflammation in the intestinal mucosa. Clin Immunol Orlando Fla 144: 190-199.

194. Van Dyken SJ and RM Locksley (2013). Interleukin-4- and interleukin-13-mediated alternatively activated macrophages: roles in homeostasis and disease. Annu Rev Immunol 31: 317-343. 
195. Graber P, D Gretener, S Herren, JP Aubry, G Elson, J Poudrier, S Lecoanet-Henchoz, S Alouani, C Losberger, JY Bonnefoy, MH Kosco-Vilbois and JF Gauchat (1998). The distribution of IL-13 receptor alpha1 expression on B cells, T cells and monocytes and its regulation by IL-13 and IL-4. Eur J Immunol 28: 42864298.

196. Hoornaert CJ, E Luyckx, K Reekmans, M Dhainaut, C Guglielmetti, D Le Blon, D Dooley, E Fransen, J Daans, L Verbeeck, A Quarta, N De Vocht, E Lemmens, H Goossens, A Van der Linden, VD Roobrouck, C Verfaillie, S Hendrix, M Moser, ZN Berneman and P Ponsaerts (2016). In vivo IL13-primed macrophages contribute to reduced alloantigen-specific $\mathrm{T}$ cell activation and prolong immunological survival of allogeneic mesenchymal stem cell implants. Stem Cells Dayt Ohio.

197. Hajizadeh-Sikaroodi S, A Hosseini, A Fallah, H Estiri, Z Noormohammadi, M Salehi, SMH Ghaderian, H Akhavan Niaki, M Soleimani and B Kazemi (2014). Lentiviral Mediating Genetic Engineered Mesenchymal Stem Cells for Releasing IL-27 as a Gene Therapy Approach for Autoimmune Diseases. Cell J 16: 255-262.

198. Le Bon A, G Schiavoni, G D’Agostino, I Gresser, F Belardelli and DF Tough (2001). Type i interferons potently enhance humoral immunity and can promote isotype switching by stimulating dendritic cells in vivo. Immunity 14: 461-470.

199. Johns TG, IR Mackay, KA Callister, PJ Hertzog, RJ Devenish and AW Linnane (1992). Antiproliferative potencies of interferons on melanoma cell lines and xenografts: higher efficacy of interferon beta. J Natl Cancer Inst 84: $1185-1190$.

200. Rosenberg SA, MT Lotze, LM Muul, S Leitman, AE Chang, SE Ettinghausen, YL Matory, JM Skibber, E Shiloni and JT Vetto (1985). Observations on the systemic administration of autologous lymphokine-activated killer cells and recombinant interleukin-2 to patients with metastatic cancer. N Engl J Med 313: 1485-1492.

201. Gaffen SL and KD Liu (2004). Overview of interleukin-2 function, production and clinical applications. Cytokine 28: 109-123.

202. Rosenberg SA, JC Yang, DE White and SM Steinberg (1998). Durability of complete responses in patients with metastatic cancer treated with high-dose interleukin-2: identification of the antigens mediating response. 
Ann Surg 228: 307-319.

203. Yang JC, RM Sherry, SM Steinberg, SL Topalian, DJ Schwartzentruber, P Hwu, CA Seipp, L RogersFreezer, KE Morton, DE White, DJ Liewehr, MJ Merino and SA Rosenberg (2003). Randomized study of highdose and low-dose interleukin-2 in patients with metastatic renal cancer. J Clin Oncol Off J Am Soc Clin Oncol 21: $3127-3132$.

204. Kobayashi M, L Fitz, M Ryan, RM Hewick, SC Clark, S Chan, R Loudon, F Sherman, B Perussia and G Trinchieri (1989). Identification and purification of natural killer cell stimulatory factor (NKSF), a cytokine with multiple biologic effects on human lymphocytes. J Exp Med 170: 827-845.

205. Wolf SF, PA Temple, M Kobayashi, D Young, M Dicig, L Lowe, R Dzialo, L Fitz, C Ferenz and RM Hewick (1991). Cloning of cDNA for natural killer cell stimulatory factor, a heterodimeric cytokine with multiple biologic effects on T and natural killer cells. J Immunol Baltim Md 1950 146: 3074-3081.

206. Cheema TA, PE Fecci, J Ning and SD Rabkin (2014). Immunovirotherapy for the treatment of glioblastoma. Oncoimmunology 3: e27218.

207. Marchi LHL, T Paschoalin, LR Travassos and EG Rodrigues (2011). Gene therapy with interleukin-10 receptor and interleukin-12 induces a protective interferon- $\gamma$-dependent response against B16F10-Nex2 melanoma. Cancer Gene Ther 18: 110-122.

208. Golab J and R Zagozdzon (1999). Antitumor effects of interleukin-12 in pre-clinical and early clinical studies (Review). Int J Mol Med 3: 537-544.

209. Rook AH, GS Wood, EK Yoo, R Elenitsas, DM Kao, ML Sherman, WK Witmer, KA Rockwell, RB Shane, SR Lessin and EC Vonderheid (1999). Interleukin-12 therapy of cutaneous T-cell lymphoma induces lesion regression and cytotoxic T-cell responses. Blood 94: 902-908.

210. Dustin ML, R Rothlein, AK Bhan, CA Dinarello and TA Springer (1986). Induction by IL 1 and interferongamma: tissue distribution, biochemistry, and function of a natural adherence molecule (ICAM-1). J Immunol Baltim Md 1950 137: 245-254. 
211. Chen W, M Li, H Cheng, Z Yan, J Cao, B Pan, W Sang, Q Wu, L Zeng, Z Li and K Xu (2013). Overexpression of the mesenchymal stem cell Cxcr4 gene in irradiated mice increases the homing capacity of these cells. Cell Biochem Biophys 67: 1181-1191.

212. Gao P, Q Ding, Z Wu, H Jiang and Z Fang (2010). Therapeutic potential of human mesenchymal stem cells producing IL-12 in a mouse xenograft model of renal cell carcinoma. Cancer Lett 290: 157-166.

213. Duan X, H Guan, Y Cao and ES Kleinerman (2009). Murine bone marrow-derived mesenchymal stem cells as vehicles for interleukin-12 gene delivery into Ewing sarcoma tumors. Cancer 115: 13-22.

214. Zhao W, J Cheng, P Shi and J Huang (2011). [Human umbilical cord mesenchymal stem cells with adenovirus-mediated interleukin 12 gene transduction inhibits the growth of ovarian carcinoma cells both in vitro and in vivo]. Nan Fang Yi Ke Da Xue Xue Bao 31: 903-907.

215. Ha SJ, J Chang, MK Song, YS Suh, HT Jin, CH Lee, GH Nam, G Choi, KY Choi, SH Lee, WB Kim and YC Sung (2002). Engineering N-glycosylation mutations in IL-12 enhances sustained cytotoxic T lymphocyte responses for DNA immunization. Nat Biotechnol 20: 381-386.

216. Han J, J Zhao, J Xu and Y Wen (2014). Mesenchymal stem cells genetically modified by lentivirusmediated interleukin-12 inhibit malignant ascites in mice. Exp Ther Med 8: 1330-1334.

217. Li X, P Zhang, X Liu and P Lv (2015). Expression of interleukin-12 by adipose-derived mesenchymal stem cells for treatment of lung adenocarcinoma. Thorac Cancer 6: 80-84.

218. Car BD, VM Eng, JM Lipman and TD Anderson (1999). The toxicology of interleukin-12: a review. Toxicol Pathol 27: 58-63.

219. Jin H-T, J-I Youn, H-J Kim, J-B Lee, S-J Ha, JS Koh and Y-C Sung (2005). Enhancement of interleukin-12 gene-based tumor immunotherapy by the reduced secretion of p40 subunit and the combination with farnesyltransferase inhibitor. Hum Gene Ther 16: 328-338.

220. Chen X, X Lin, J Zhao, W Shi, H Zhang, Y Wang, B Kan, L Du, B Wang, Y Wei, Y Liu and X Zhao (2008). A tumor-selective biotherapy with prolonged impact on established metastases based on cytokine gene- 
engineered MSCs. Mol Ther J Am Soc Gene Ther 16: 749-756.

221. Bergelson JM, JA Cunningham, G Droguett, EA Kurt-Jones, A Krithivas, JS Hong, MS Horwitz, RL Crowell and RW Finberg (1997). Isolation of a common receptor for Coxsackie B viruses and adenoviruses 2 and 5. Science 275: 1320-1323.

222. Shiver JW and EA Emini (2004). Recent advances in the development of HIV-1 vaccines using replicationincompetent adenovirus vectors. Annu Rev Med 55: 355-372.

223. Jing W, Y Chen, L Lu, X Hu, C Shao, Y Zhang, X Zhou, Y Zhou, L Wu, R Liu, K Fan and G Jin (2014). Human umbilical cord blood-derived mesenchymal stem cells producing IL15 eradicate established pancreatic tumor in syngeneic mice. Mol Cancer Ther 13: 2127-2137.

224. Jaiswal PK, V Singh, P Srivastava and RD Mittal (2013). Association of IL-12, IL-18 variants and serum IL-18 with bladder cancer susceptibility in North Indian population. Gene 519: 128-134.

225. Ossendorp F, E Mengedé, M Camps, R Filius and CJ Melief (1998). Specific T helper cell requirement for optimal induction of cytotoxic T lymphocytes against major histocompatibility complex class II negative tumors. J Exp Med 187: 693-702.

226. Ni J, M Miller, A Stojanovic, N Garbi and A Cerwenka (2012). Sustained effector function of IL-12/15/18preactivated NK cells against established tumors. J Exp Med 209: 2351-2365.

227. Shen Z, H Seppänen, S Vainionpää, Y Ye, S Wang, H Mustonen and P Puolakkainen (2012). IL10, IL11, IL18 are differently expressed in CD14+ TAMs and play different role in regulating the invasion of gastric cancer cells under hypoxia. Cytokine 59: 352-357.

228. Crende O, M Sabatino, M Valcárcel, T Carrascal, P Riestra, JA López-Guerrero, E Nagore, S Mandruzzato, E Wang, FM Marincola and F Vidal-Vanaclocha (2013). Metastatic lesions with and without interleukin-18dependent genes in advanced-stage melanoma patients. Am J Pathol 183: 69-82.

229. Xu G, X-D Jiang, Y Xu, J Zhang, F-H Huang, Z-Z Chen, D-X Zhou, J-H Shang, Y-X Zou, Y-Q Cai, S-B Kou, Y-Z Chen, R-X Xu and Y-J Zeng (2009). Adenoviral-mediated interleukin-18 expression in mesenchymal 
stem cells effectively suppresses the growth of glioma in rats. Cell Biol Int 33: 466-474.

230. Xu G, Y Guo, Z Seng, G Cui and J Qu (2015). Bone marrow-derived mesenchymal stem cells coexpressing interleukin-18 and interferon- $\beta$ exhibit potent antitumor effect against intracranial glioma in rats. Oncol Rep 34: 1915-1922.

231. Sun S, X Liu, D Jiang, Z Lü and F Li (2014). [Effect of interleukin-18 gene modified human umbilical cord mesenchymal stem cells on proliferation of breast cancer cell]. Zhonghua Yi Xue Za Zhi 94: 2013-2017.

232. Liu X, J Hu, S Sun, F Li, W Cao, YU Wang, Z Ma and Z Yu (2015). Mesenchymal stem cells expressing interleukin-18 suppress breast cancer cells in vitro. Exp Ther Med 9: 1192-1200.

233. Dou J, Y Wang, J Wang, F Zhao, Y Li, M Cao, W Hu, K Hu, XF He, L Chu, C Jiang and N Gu (2009). Antitumor efficacy induced by human ovarian cancer cells secreting IL-21 alone or combination with GM-CSF cytokines in nude mice model. Immunobiology 214: 483-492.

234. Kim-Schulze S, HS Kim, Q Fan, DW Kim and HL Kaufman (2009). Local IL-21 promotes the therapeutic activity of effector $\mathrm{T}$ cells by decreasing regulatory $\mathrm{T}$ cells within the tumor microenvironment. Mol Ther $\mathrm{J}$ Am Soc Gene Ther 17: 380-388.

235. Zhang Y, J Wang, M Ren, M Li, D Chen, J Chen, F Shi, X Wang and J Dou (2014). Gene therapy of ovarian cancer using IL-21-secreting human umbilical cord mesenchymal stem cells in nude mice. J Ovarian Res 7: 8.

236. Kim N, Y-S Nam, K-I Im, J-Y Lim, E-S Lee, Y-W Jeon and S-G Cho (2015). IL-21-Expressing Mesenchymal Stem Cells Prevent Lethal B-Cell Lymphoma Through Efficient Delivery of IL-21, Which Redirects the Immune System to Target the Tumor. Stem Cells Dev 24: 2808-2821.

237. Li Q, K Kawamura, Y Tada, H Shimada, K Hiroshima and M Tagawa (2013). Novel type III interferons produce anti-tumor effects through multiple functions. Front Biosci Landmark Ed 18: 909-918.

238. Lasfar A, W Abushahba, M Balan and KA Cohen-Solal (2011). Interferon lambda: a new sword in cancer immunotherapy. Clin Dev Immunol 2011: 349575. 
239. Fujie H, T Tanaka, M Tagawa, N Kaijun, M Watanabe, T Suzuki, K Nakayama and M Numasaki (2011). Antitumor activity of type III interferon alone or in combination with type I interferon against human non-small cell lung cancer. Cancer Sci 102: 1977-1990.

240. Lasfar A, A Lewis-Antes, SV Smirnov, S Anantha, W Abushahba, B Tian, K Reuhl, H Dickensheets, F Sheikh, RP Donnelly, E Raveche and SV Kotenko (2006). Characterization of the mouse IFN-lambda ligandreceptor system: IFN-lambdas exhibit antitumor activity against B16 melanoma. Cancer Res 66: 4468-4477.

241. Numasaki M, M Tagawa, F Iwata, T Suzuki, A Nakamura, M Okada, Y Iwakura, S Aiba and M Yamaya (2007). IL-28 elicits antitumor responses against murine fibrosarcoma. J Immunol Baltim Md 1950 178: 50865098.

242. Shahrokhi S, S Daneshmandi and F Menaa (2014). Tumor necrosis factor- $\alpha / C D 40$ ligand-engineered mesenchymal stem cells greatly enhanced the antitumor immune response and lifespan in mice. Hum Gene Ther 25: $240-253$.

243. Carmelo JG, A Fernandes-Platzgummer, JMS Cabral and CL da Silva (2015). Scalable ex vivo expansion of human mesenchymal stem/stromal cells in microcarrier-based stirred culture systems. Methods Mol Biol Clifton NJ 1283: 147-159.

244. Hynes K, D Menicanin, K Mrozik, S Gronthos and PM Bartold (2014). Generation of functional mesenchymal stem cells from different induced pluripotent stem cell lines. Stem Cells Dev 23: 1084-1096.

245. Kang R, Y Zhou, S Tan, G Zhou, L Aagaard, L Xie, C Bünger, L Bolund and Y Luo (2015). Mesenchymal stem cells derived from human induced pluripotent stem cells retain adequate osteogenicity and chondrogenicity but less adipogenicity. Stem Cell Res Ther 6: 144.

246. Roberts I, S Baila, RB Rice, ME Janssens, K Nguyen, N Moens, L Ruban, D Hernandez, P Coffey and C Mason (2012). Scale-up of human embryonic stem cell culture using a hollow fibre bioreactor. Biotechnol Lett 34: 2307-2315.

247. Sheu J, J Beltzer, B Fury, K Wilczek, S Tobin, D Falconer, J Nolta and G Bauer (2015). Large-scale production of lentiviral vector in a closed system hollow fiber bioreactor. Mol Ther Methods Clin Dev 2: 15020. 
248. Giangrande P (2016). The Future of Hemophilia Treatment: Longer-Acting Factor Concentrates versus Gene Therapy. Semin Thromb Hemost.

249. He T, G Chi, B Tian, T Tang and K Dai (2015). Lentivirus transduced interleukin-1 receptor antagonist gene expression in murine bone marrow-derived mesenchymal stem cells in vitro. Mol Med Rep 12: 4063-4070.

250. Lin J-Q, C-Z Lin, X-Z Lin, K Zeng and Y-G Gao (2012). Construction of a bicistronic recombinant adenoviral vector for human interleukin-10 and enhanced green fluorescent protein expression in bone marrow mesenchymal stem cells. Chin Med J (Engl) 125: 102-108.

251. Xu J-R, H-X Li, G-Q Wang, X-B Du, Y-Q Wei and J-M Zhao (2009). [Screening and identification of mesenchymal stem cell strains to secret mouse interleukin-12 mediated with lenti-viral vector]. Sichuan Da Xue Xue Bao Yi Xue Ban 40: 584-587.

252. Seo SH, KS Kim, SH Park, YS Suh, SJ Kim, S-S Jeun and YC Sung (2011). The effects of mesenchymal stem cells injected via different routes on modified IL-12-mediated antitumor activity. Gene Ther 18: 488-495.

253. Ryu CH, S-H Park, SA Park, SM Kim, JY Lim, CH Jeong, W-S Yoon, W Oh, YC Sung and S-S Jeun (2011). Gene therapy of intracranial glioma using interleukin 12-secreting human umbilical cord blood-derived $\begin{array}{llllll}\text { mesenchymal } & \text { stem } & \text { cells. } & \text { Hum } & \text { T33-743. }\end{array}$ 


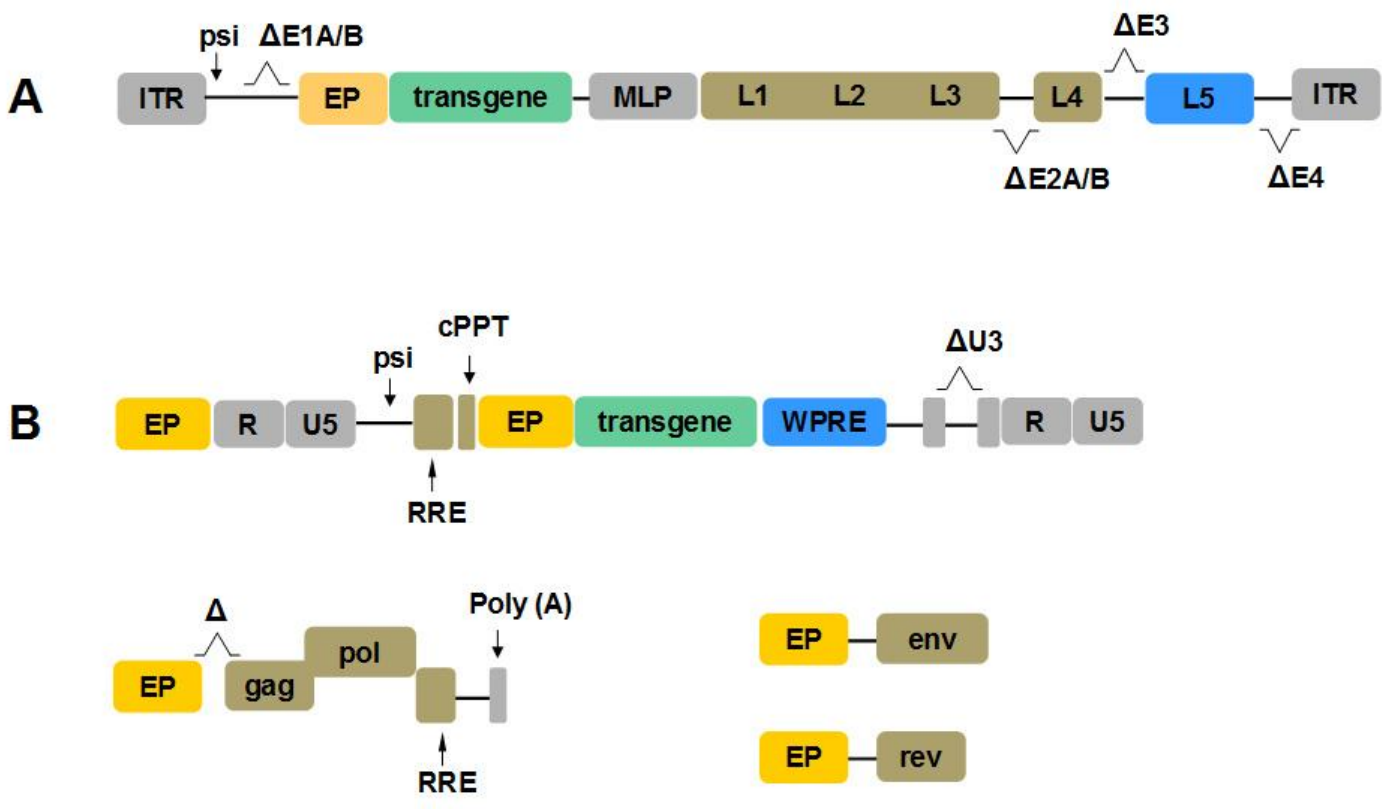

Figure 1. Schematic of adenoviral (Adv) and lentiviral (LV) vector genomes. A. Parental Adv isolate, usually of serotype 2 or 5 , is deleted of most early (indicated with an E and light blue) genes and other regulatory genes and retain most structural genes, major late promoter (MLP, shown in grey) and inverted terminal repeats (ITR, terminal promoters, shown in grey). Transgene (light green) and its eukaryotic promoter (EP, shown in yellow) replace E1A/E1B genes. B. To minimize risks of generating infectious particles, the third generation vector is produced with the viral genes provided by four separated constructs. The vector genome showed here is a selfinactivating type that is obtained by deleting the U3 region of 5'LTR (shown in grey); U3 deletion abolishes 5'LTR promoter activity and is transferred to 3'LTR during reverse transcription. From the parental genome, the vector retains the encapsidation signal (psi), the Rev-responsive element (RRE) necessary for Rev-driven nuclear-cytoplasmic exportation of viral messenger RNAs, and the central poly-purine tract (cPPT). It also contains the woodchuck hepatitis post-transcriptional regulatory element (WPRE) that increases efficiency of vector RNA encapsidation and post-transcriptional processing of transgene RNA, respectively. The EP placed upstream of 5'LTR drives expression of the genome construct as well as of the three other constructs. The packaging construct encodes capsid and enzyme proteins and lacks encapsidation signal. Rev and envelope proteins are provided in trans with remaining two DNA plasmids. 
Table 1. Pros and cons of adenoviral, adeno-associated, and lentiviral vectors

\begin{tabular}{|c|c|c|}
\hline Adenoviral & Adeno-associated & Lentiviral \\
\hline \multicolumn{3}{|l|}{ Advantages } \\
\hline $\begin{array}{l}\text { Transduce non-dividing and dividing } \\
\text { cells }\end{array}$ & Transduce non-dividing and dividing cells & Transduce non-dividing and dividing cells \\
\hline Carry up to $8 \mathrm{Kbp}$ heterologous DNA & Parental virus apathogenic & Carry up to $9 \mathrm{Kbp}$ heterologous DNA \\
\hline $\begin{array}{l}\text { High and short-term transgene } \\
\text { expression }\end{array}$ & Wide cellular tropism & High and long-term transgene expression \\
\hline Fast and high titer production & Potential site-specific integration & Stable transduction \\
\hline Good oncolytic and vaccine vector & Low immunogenic & Easy to re-target and produce \\
\hline \multicolumn{3}{|l|}{ Disadvantages } \\
\hline Highly immunogenic & Carry up to $5 \mathrm{Kbp}$ heterologous DNA & Risk of insertional mutagenesis \\
\hline High levels of pre-existing immunity & High titer preparations difficult to obtain & High titer preparations difficult to obtain \\
\hline $\begin{array}{l}\text { The genome persists as episome and is } \\
\text { not transmitted to progeny cells }\end{array}$ & $\begin{array}{l}\text { Current vectors are unable to integrate their } \\
\text { genome into host cell genome }\end{array}$ & $\begin{array}{l}\text { Incorporation of some viral regulatory } \\
\text { proteins in vector particles }\end{array}$ \\
\hline Transient expression of the transgene & $\begin{array}{l}\text { Production requires co-infection by a helper } \\
\text { virus }\end{array}$ & $\begin{array}{l}\text { Transient expression of the transgene with } \\
\text { integration-defective vector }\end{array}$ \\
\hline
\end{tabular}


Table 2: MSCs engineered with anti-inflammatory cytokines

\begin{tabular}{|c|c|c|}
\hline $\begin{array}{c}\text { MSC } \\
\text { source }\end{array}$ & Gene & Model \\
\hline $\begin{array}{l}\text { hBM- } \\
\text { MSC }\end{array}$ & IL-1Ra & $\begin{array}{c}\text { streptozotocin-induced } \\
\text { diabetic (NOD-SCID*) } \\
\text { mice }\end{array}$ \\
\hline $\begin{array}{l}\mathrm{hBMM} \\
\mathrm{SC}\end{array}$ & IL-1Ra & In vitro \\
\hline $\begin{array}{l}\text { mBM- } \\
\text { MSC }\end{array}$ & IL-1Ra & In vitro \\
\hline $\begin{array}{l}\text { hBM- } \\
\text { MSC }\end{array}$ & $\begin{array}{l}\text { IL-1 } \beta / \\
\text { TNF- } \alpha\end{array}$ & In vitro \\
\hline $\begin{array}{l}\text { pig BM- } \\
\text { MSC }\end{array}$ & IL-4 & $\begin{array}{c}\text { ASNHL } * * \text { guinea pig } \\
\text { model }\end{array}$ \\
\hline $\begin{array}{l}\text { hAT- } \\
\text { MSC }\end{array}$ & IL-4 & $\mathrm{EAE}^{* * *}$ model \\
\hline $\begin{array}{l}\text { rBM- } \\
\text { MSC }\end{array}$ & IL-10 & In vitro study \\
\hline $\begin{array}{l}\text { rBM- } \\
\text { MSC }\end{array}$ & IL-10 & $\begin{array}{l}\text { Orthotopic liver } \\
\text { transplantation }\end{array}$ \\
\hline
\end{tabular}

Arthritis therapy

Results

Reference

Improve islet

$\mathrm{hBM}-$

$[155-156]$

transplantation

MSC/HGF/IL-

1Ra prevent

apoptosis of islet

cells caused by

inflammatory

cytokines.

MSCs/IL-1Ra

support MSC

chondrogeneic

differentiation

LV/IL-1Ra

Evaluate MSC

efficiently

transduction

transduce MSCs

and improve cell

viability.

cartilage regeneration

IL- $1 \beta$ and TNF- $\alpha$ inhibit

chondrogenic

differentiation of MSCs

AIED treatment
Therapy of
autoimmune
demyelination
Evaluate the
efficiency of MSC
ransduction by Adv-
IL10/GFP

Restoration of auditory function

Improvement of EAE

Prevention of allograft rejection

MSCs were

efficiently

transduced and

produced IL-10

MSC/IL-10

improve graft

survival

increasing Treg cells

hWJ- IL-10 In vitro

Efficiency of

Morphology,

phenotype and function of $\mathrm{hWJ}$ -

MSC were not altered by transduction

MSC transduction

Reduction of

hWJ- vIL-10 In vitro

Potentiation of MSC

immunosuppressive

IFN- $\gamma$ and TNF- $\alpha$ properties secretion 


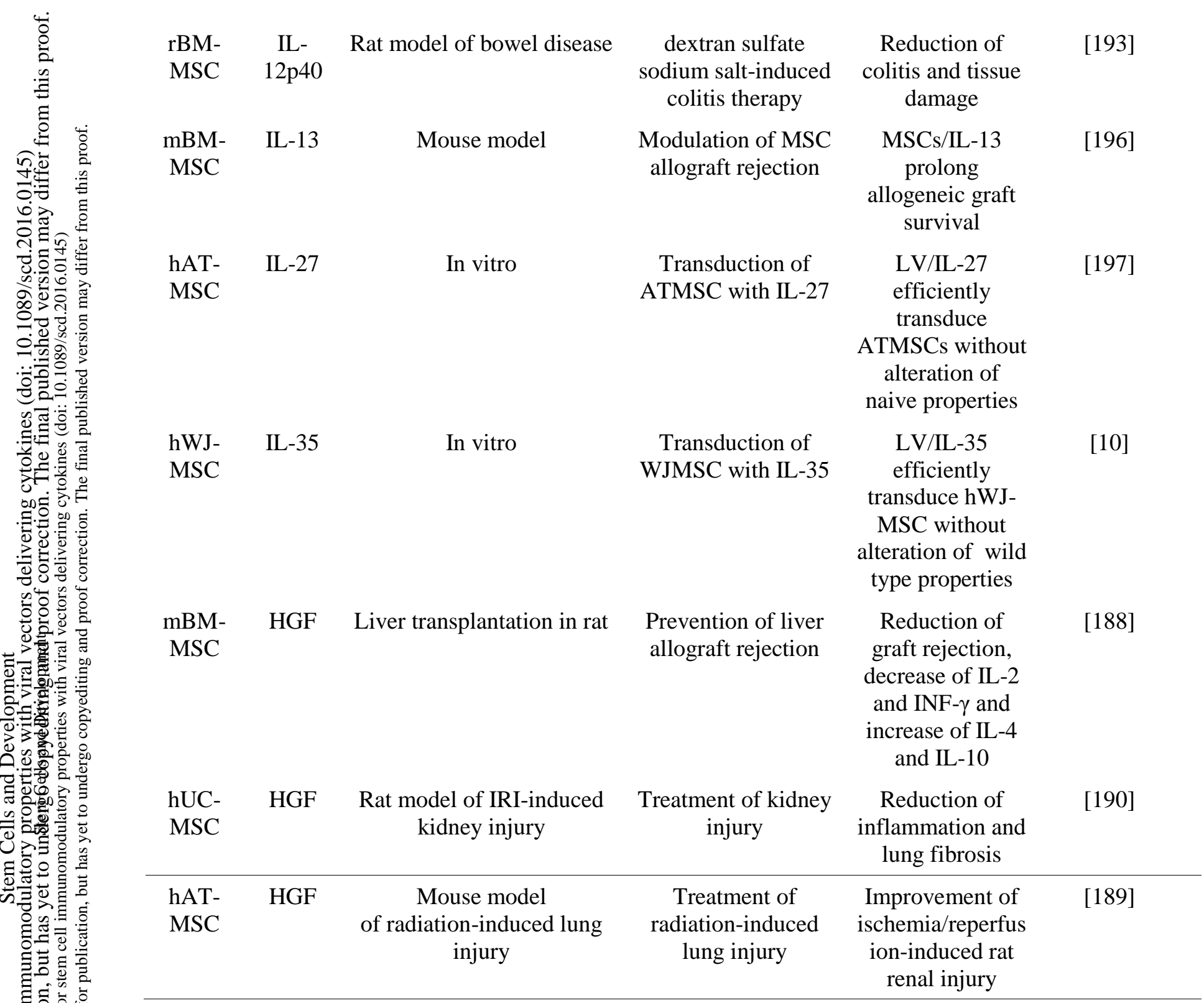

* non-obese diabetic/severe combined immunodeficiency

**Autoimmune sensorineural hearing loss

*** Experimental autoimmune encephalomyelitis 
Table 3: MSC engineered with pro-inflammatory cytokines

\begin{tabular}{|c|c|c|c|c|c|}
\hline $\begin{array}{c}\text { MSC } \\
\text { source }\end{array}$ & Gene & Model & Aim & Results & $\begin{array}{c}\text { Referenc } \\
\text { e }\end{array}$ \\
\hline hBM-MSC & $\begin{array}{c}\text { INF- } \\
\beta\end{array}$ & Melanoma bearing mice & $\begin{array}{l}\text { To transduce SC } \\
\text { with INF- } \beta \text { and } \\
\text { assess antitumor } \\
\text { activity }\end{array}$ & $\begin{array}{l}\text { Inhibition of } \\
\text { melanoma growth }\end{array}$ & {$[8,112]$} \\
\hline rBM-MSC & IL-2 & rat model of glioma & Glioma therapy & $\begin{array}{l}\text { Reduction of } \\
\text { tumor mass }\end{array}$ & [106] \\
\hline mBM-MSC & IL-12 & $\begin{array}{l}\text { experimental model of animal } \\
\text { bearing melanoma, breast } \\
\text { tumor, and hepatoma }\end{array}$ & Cancer therapy & $\begin{array}{l}\text { Reduction of } \\
\text { tumor mass and } \\
\text { metastases }\end{array}$ & [211] \\
\hline mBM-MSC & IL-12 & $\begin{array}{l}\text { Mice bearing human Ewing's } \\
\text { Sarcoma }\end{array}$ & $\begin{array}{l}\text { Ewing's Sarcoma } \\
\text { Tumors therapy }\end{array}$ & $\begin{array}{l}\text { Suppression of } \\
\text { tumor growth }\end{array}$ & [213] \\
\hline mBM-MSC & IL-12 & In vitro study & $\begin{array}{c}\text { LV vector } \\
\text { transduction of } \\
\text { mBM-MSC with IL- } \\
12\end{array}$ & $\begin{array}{l}\text { mBM-MSC were } \\
\text { efficiently } \\
\text { transduced }\end{array}$ & [251] \\
\hline hBM-MSC & IL-12 & Mouse model of renal cancer & $\begin{array}{l}\text { Renal carcinoma } \\
\text { therapy }\end{array}$ & $\begin{array}{l}\text { Reduction of } \\
\text { renal cancer } \\
\text { growth }\end{array}$ & [212] \\
\hline rBM-MSC & IL-12 & $\begin{array}{l}\text { melanoma and cervical cancer } \\
\text { experimental models }\end{array}$ & Antitumor activity & $\begin{array}{l}\text { Reduction of } \\
\text { tumor mass and } \\
\text { metastases }\end{array}$ & [252] \\
\hline hAT-MSC & IL-12 & In vitro study & $\begin{array}{l}\text { lung } \\
\text { adenocarcinoma } \\
\text { therapy }\end{array}$ & $\begin{array}{l}\text { hAT-MSCs/IL-12 } \\
\text { induce apoptosis } \\
\text { of A549 cell }\end{array}$ & [217] \\
\hline mBM-MSC & IL-12 & Tumor bearing mice & $\begin{array}{l}\text { Malignant ascites } \\
\text { treatment }\end{array}$ & $\begin{array}{l}\text { Inhibition of } \\
\text { ascites }\end{array}$ & [216] \\
\hline hUC-MSC & IL-12 & SKOV3 tumor bearing mice & $\begin{array}{l}\text { Ovarian cancer } \\
\text { treatment }\end{array}$ & $\begin{array}{l}\text { hUC-MSC/IL12 } \\
\text { inhibit SKOV3 } \\
\text { growth }\end{array}$ & [214] \\
\hline hUC-MSC & $\begin{array}{c}\mathrm{IL}- \\
12 \mathrm{M} \\
*\end{array}$ & mouse model of glioma & Treatment of glioma & $\begin{array}{l}\text { hUC- } \\
\text { MSC/IL12M } \\
\text { inhibit tumor } \\
\text { growth and } \\
\text { prolong animal } \\
\text { survival }\end{array}$ & [253] \\
\hline hUCB-MSC & IL-15 & $\begin{array}{l}\text { mouse Pan02 pancreatic tumor } \\
\text { model }\end{array}$ & $\begin{array}{l}\text { Pancreatic tumor } \\
\text { therapy }\end{array}$ & $\begin{array}{l}\text { Inhibition of } \\
\text { tumor growth and } \\
\text { immunitation }\end{array}$ & [223] \\
\hline rBM-MSC & IL-18 & rat glioma model & Glioma Therapy & $\begin{array}{l}\text { Partial inhibiton } \\
\text { of Glioma growth }\end{array}$ & [229] \\
\hline hUC-MSC & IL-18 & In vitro study & Assessment of anti- & HUC-MSCs/IL- & [231-232] \\
\hline
\end{tabular}




\begin{tabular}{|c|c|c|c|c|c|}
\hline & & & $\begin{array}{l}\text { breast cancer activity } \\
\text { of MSC/IL-18 }\end{array}$ & $\begin{array}{l}18 \text { inhibit breast } \\
\text { cancer } \\
\text { proliferation in } \\
\text { vitro }\end{array}$ & \\
\hline BM-MSC & $\begin{array}{l}\text { IL- } \\
18 / \mathrm{IF} \\
\mathrm{N} \beta\end{array}$ & Intracranial glioma rat model & Glioma therapy & $\begin{array}{l}\text { Inhibiton of } \\
\text { Glioma growth }\end{array}$ & [230] \\
\hline hUCB-MSC & IL-21 & $\begin{array}{c}\text { Nude mice SKOV3 ovarian } \\
\text { cancer model }\end{array}$ & $\begin{array}{l}\text { Ovarian cancer } \\
\text { therapy }\end{array}$ & $\begin{array}{c}\text { Anti-tumor effect } \\
\text {, upregulation of } \\
\text { NK, IFN- } \gamma \text { and } \\
\text { TNF- } \alpha\end{array}$ & [235] \\
\hline hUCB-MSC & IL-21 & $\begin{array}{c}\text { A } 20 \text { B-cell lymphoma mouse } \\
\text { model }\end{array}$ & $\begin{array}{l}\text { B-cell lymphoma } \\
\text { therapy }\end{array}$ & $\begin{array}{l}\text { delayed tumor } \\
\text { incidence and } \\
\text { improved survival }\end{array}$ & [236] \\
\hline hBM-MSC & $\begin{array}{l}\text { IL- } \\
28 \mathrm{~A}\end{array}$ & In vitro study & $\begin{array}{l}\text { assess anti-tumor } \\
\text { effect on human lung } \\
\text { carcinoma cells of } \\
\text { MSC/IL-28A }\end{array}$ & $\begin{array}{l}\text { Inhibition of } \\
\text { tumor growth and } \\
\text { angiogenesis }\end{array}$ & [125] \\
\hline mBM-MSC & $\begin{array}{l}\text { TNF } \alpha \\
\text { /CD4 } \\
0\end{array}$ & Mouse breast cancer model & $\begin{array}{l}\text { Breast Cancery } \\
\text { Therapy }\end{array}$ & $\begin{array}{c}\text { Inhibition of } \\
\text { tumor growth and } \\
\text { prolonging animal } \\
\text { survival }\end{array}$ & [242] \\
\hline
\end{tabular}

*IL-12p40N220Q 